\title{
Charcoal or black stone? Reconstructions as a tool to study the behaviour of dry underdrawing materials within the paint structure of sixteenth century panel paintings
}

\author{
H. P. Melo ${ }^{1,2^{*}}$ (D), Sara Valadas ${ }^{1,2}$, António João Cruz $^{1,3}$ and António Candeias ${ }^{1,2}$
}

\begin{abstract}
Reconstructions were used as a tool to investigate the use of charcoal and black stone as underdrawing materials in sixteenth century panel paintings with white or off-white preparatory layers. Research was based on the examination of a group of sixteenth century panel paintings by the Portuguese Mannerist painter Francisco João (doc. 1558-1595) and his workshop. Analysis of the original underdrawing material in cross-sections, using microscopic and spectroscopic techniques was not always conclusive. Based on materials thought to be employed by Francisco João and on data collected from sixteenth and seventeenth century European technical treatises along with published analytical studies of panel paintings with white or off-white preparatory layers from this period, reconstructions were performed using charcoal (untreated and oiled - as described in contemporary literature) and natural black stone over different preparatory surfaces. Microscopic analyses of cross-sections from reconstructions were made to assist the discussion of the behaviour of the dry underdrawing media within the paint structure. Results revealed that whereas charcoal could be easily removed if drawn directly over gesso, it would remain fixed when drawn over a ground treated with an oil-based intermediate layer, even when the latter was completely dry to the touch. The persistence of a charcoal drawing when applied over oil challenged the widely disseminated assumption that naturally occurring black stone, which makes a permanent mark, had been employed more frequently than charcoal since the latter appeared to be easily disturbed and hence transitory. The very lengthy curing time for a drying oil could be responsible for fixing the friable media. Reconstructions further showed that oiled charcoal is easily prepared and agreeable to use on any type of surface, where it remains without smudging. Finally, research suggests that the painter's choice of underdrawing material is closely dependent on the nature of the binder of intermediate layers and on the position of the underdrawing layout within the paint structure.
\end{abstract}

Keywords: Underdrawing, Sixteenth century, Painting, Oil, Charcoal, Black stone, Historical reconstructions

\section{Introduction}

This paper uses reconstructions to investigate the behaviour of charcoal and black stone as underdrawing materials within the complex multi-layered system

\footnotetext{
*Correspondence: manahelena@gmail.com

1 HERCULES Laboratory, University of Évora, Palácio do Vimioso, Largo

Marquês de Marialva 8, 7000-809 Évora, Portugal

Full list of author information is available at the end of the article
}

of sixteenth century panel paintings with white or off-white preparatory layers. Research is based on the examination of a group of sixteenth century panel paintings by the Portuguese Mannerist painter Francisco João (doc. 1558-1595) and his workshop where an extensive underdrawing that could have been either accomplished with charcoal or black stone was detected during infrared examination [1]. The paintings are dated circa $1570-80$ and belong to three altarpieces
Springer Open

(c) The Author(s) 2022. Open Access This article is licensed under a Creative Commons Attribution 4.0 International License, which permits use, sharing, adaptation, distribution and reproduction in any medium or format, as long as you give appropriate credit to the original author(s) and the source, provide a link to the Creative Commons licence, and indicate if changes were made. The images or other third party material in this article are included in the article's Creative Commons licence, unless indicated otherwise in a credit line to the material. If material is not included in the article's Creative Commons licence and your intended use is not permitted by statutory regulation or exceeds the permitted use, you will need to obtain permission directly from the copyright holder. To view a copy of this licence, visit http://creativecommons.org/licenses/by/4.0/. The Creative Commons Public Domain Dedication waiver (http://creativeco mmons.org/publicdomain/zero/1.0/) applies to the data made available in this article, unless otherwise stated in a credit line to the data. 


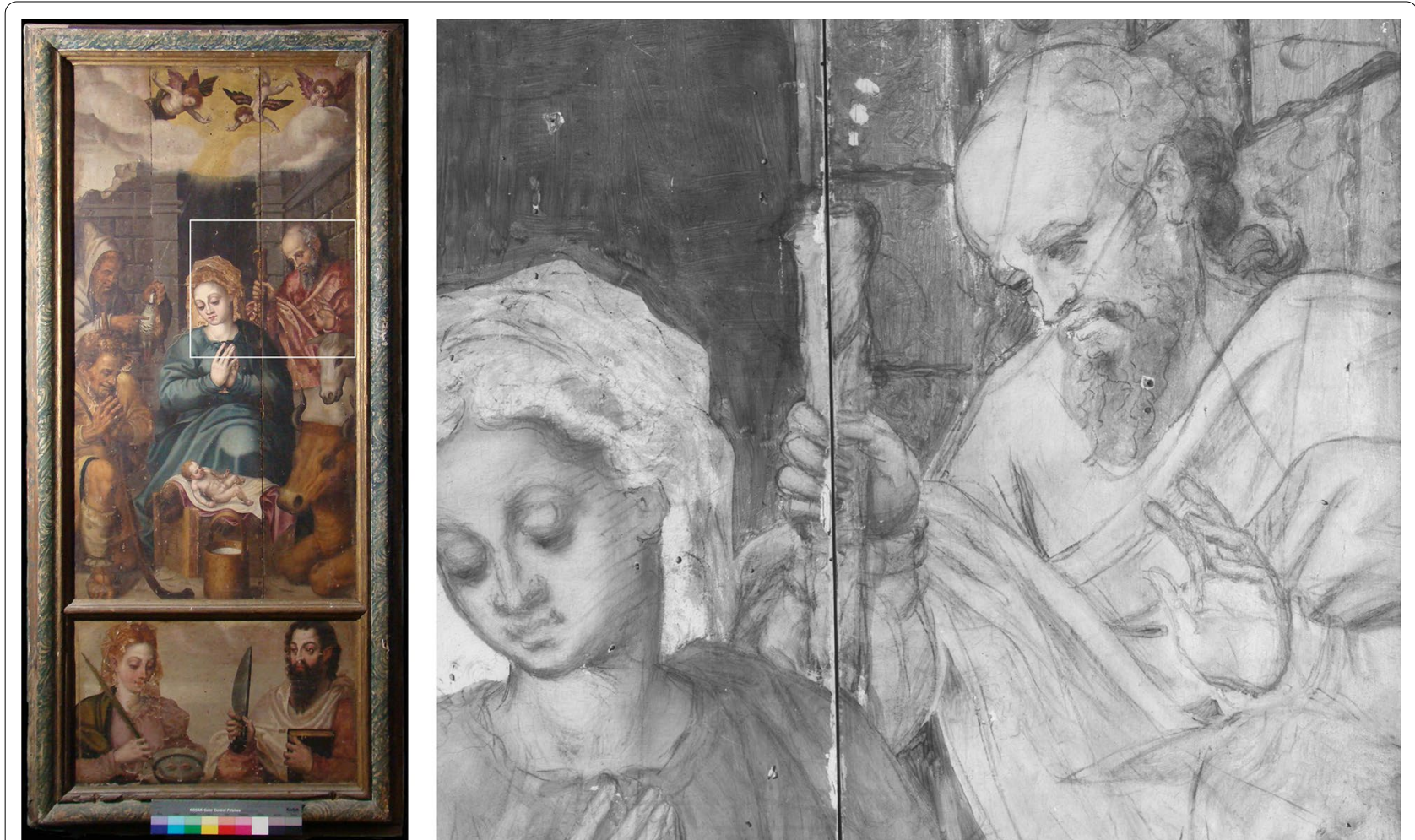

Fig. 1 Painting from the Machede Altarpiece $(196 \times 92 \mathrm{~cm}$; Alentejo, Portugal) showing the area that appears in the infrared detail on the right. Vis, IRR OHPM; IRR Digital assembly ONuno Carriço, HERCULES Lab—U. Évora, Portugal

from the churches of Machede (Fig. 1), São Francisco and Sousel, in southern Portugal. Analysis of the underdrawing material in cross-sections, using microscopic and spectroscopic techniques was not always conclusive. In fact, making the distinction between charcoal and black stone in underdrawings is problematic since they appear very similar in both visual and chemical analyses (see below).

Charcoal is classified as a char made by the carbonization of plant matter in the absence of oxygen [2] whereas black stone is said to be a carbonaceous shale or argillaceous schist containing amorphous carbon and, in some cases, graphite as the colouring material [3-5]. Black stone, also named 'black chalk', is in fact a generic term referring to a black mineral of variable composition that could be used for drawing or as a pigment $[2,6,7]$. In addition, it is possible that black stone was used in historical sources to name graphite or ampelite $[8,9]$.

While Raman spectroscopy has been successful in discriminating between different types of carbon-containing black drawing or painting materials [10-14], these studies have mainly focused on reference materials, black pigments in paint layers or drawing media in artworks on paper, all of which provide more direct access to the materials analysed.
In the case of paintings, successful identification of underdrawing materials through chemical analyses is hampered by the small sample size and interference from surrounding materials present in the preparatory and paint layers. In addition, micro-sampling from original artworks is not always possible. Despite this, the use of black stone versus charcoal has been found in underdrawing using a combination of infrared examination of the paint surface, microscopic characterisation and elemental analysis of underdrawing particles [15-17].

More often however, to complement inconclusive analytical data or overcome the lack of analysis, investigations make use of infrared imaging techniques in an effort to determine the nature of the underdrawing. Where visual evidence appears to eliminate the use of a fluid medium or metal point, researchers propose the use of black stone [18-20]. In other instances, a dry medium is mentioned without specifying its nature, or else an adjective indicating doubt is used, for instance "probably black chalk" [18, 21-26]. The interpretation that black stone was used likely relies on the common assumption that because charcoal is easily erased it has a transitory function when used in the underdrawing stage of oil painting and consequently, naturally occurring black stone-which makes a permanent mark and 
whose appearance under infrared reflectography can be mistaken for charcoal-would most commonly have been used [18-20, 27-29]. Fabricated black drawing sticks could also have been used but these are impossible to distinguish from natural sticks and often contain, beyond a binder, a mixture of carbon-based materials that hinder any analytical identification of their components [30].

To expand the initial analytical approach, reconstructions were made using charcoal (untreated and oiled, as described in the contemporary literature) and black stone over a gesso ground with and without oil layers added. The design of a systematic methodology for the reconstructions was based on (1) the study of the Portuguese panel paintings aforementioned; (2) the research of European treatises, mainly from the sixteenth and seventeenth centuries along with published analytical studies of panel paintings with white or off-white preparatory layers from this period; and (3) microscopic analysis of cross-sections from a selection of 9 year-old reconstructions.

Considering the practice of panel painting in oil over aqueous-based white or off-white grounds, historical technical treatises [31] advise the use of an overall isolation layer and/or an overall 'imprimatura' layer to seal the relatively absorbent ground. In this investigation, 'isolation layer' refers to unpigmented layers and 'imprimatura' to those layers containing pigments, independent of the nature of the binder, thickness and degree of transparency [31, 32]. In this text both will also be referred to as 'intermediate layers' [33].

\section{Historical references to the use of charcoal and black stone for underdrawing}

In the historical documents examined, charcoal and black stone are mostly mentioned in the context of drawing on paper (Table 1).

In terms of charcoal, Vasari (1511-1574) is the only author who considered it a useful tool for the underdrawing stage in panel painting due to the fact that it could be easily erased [29: p. 231]. The impermanent nature of charcoal had been acknowledged at the end of the fourteenth century by Cennini [27: p. 78, 222-224] and repeated, not only by Vasari in 1550 [28, 29], but by many others such as De Mayerne (1620-46) [34: p. 230] or De Nismes (1660-1737) [35: p.13]. It was considered an advantage since it enabled corrections, particularly useful for beginners as noted by, among others, Cennini [27: p. 77-78] and De Nismes [35: p. 13]. The advice given by Volpato (1633-1706) to treat charcoal sticks with "common oil" was intended to overcome the problem of easily losing charcoal lines [36: p. 752].

The sources consulted mention powdered charcoal for the transfer of a design onto different surfaces, especially in the context of mural painting. Regarding panel paintings, authors refer to a black powder or to the act of transfer without specifying the exact nature of the material used, possibly because several coloured powders would be suited for that task. For this purpose, Van Mander (1548-1606) notes that Italians used chalk or a similar material whereas his predecessors used a "dark substance" [37, 38: p. 171-173]. Charcoal dust is specifically mentioned by Vasari and in the Spanish manuscript from the end of the sixteenth century Reglas para pintar $[29,39]$ (Table 1). Powdered charcoal and, less frequently, powdered black stone are also recommended for shading drawings on paper, namely cartoons, by Armenini (15301609) [40: p. 254] and Du Grez (1640-1720) [41: p. 173]. The Volpato Manuscript ( $>1670)$ describes the act of anointing a charcoal stick with "common oil, so that when used the marks may not be cancelled" [36: p. 752]. Traces of this technique are suspected in drawings on paper $[4,42]$ and its use in the underdrawing stage could not be ruled out, although no reference to this practice was found in the historical sources consulted.

As for black stone, comments on the degree of softness of the black stone, (e.g., by Cennini and De Mayerne), indicate that several qualities of black stone would have been available [27: p. 85, 34: p. 230]. Indeed, several places of origin have been identified: Italy (Cennini), France [Vasari and Baldinucci (1625-1696)] and Spain (Baldinucci) [27: p. 85, 29: p. 213, 43: p. 92]. As noted by Bomford et al. [3], Lomazzo (1538-1592) mentions a stone coming from Germany which could correspond to black stone. The sole references found in the context of panel painting are made by Van Mander and De Mayerne (Table 1). Both authors point out that black stone is used to reinforce a previous underdrawing done freehand or by tracing, thus implying its permanent character [38: $\mathrm{p}$. 173, 34: p. 230].

Some researchers indicate there was a preference for black stone as a drawing material for independent drawings on paper from the late fifteenth century and note its wide adoption in the sixteenth century $[4,44]$ which suggests that this material was easily available at the time. Its use in the underdrawing stage of panel painting, however, requires further research and will possibly remain unknown since fabricated black drawing sticks could also have been available [30].

As for the location of the underdrawing within the paint structure, information regarding the practice of painting on panel with an aqueous ground becomes rare against the growing instructions concerning canvas paintings with oil-based grounds [31]. Yet, of the five authors attentive to this detail, four specifically state that the underdrawing should be done over the imprimatura [29, 45-47] while the fifth, Van Mander, indicates it would be underneath the imprimatura (note that he was 


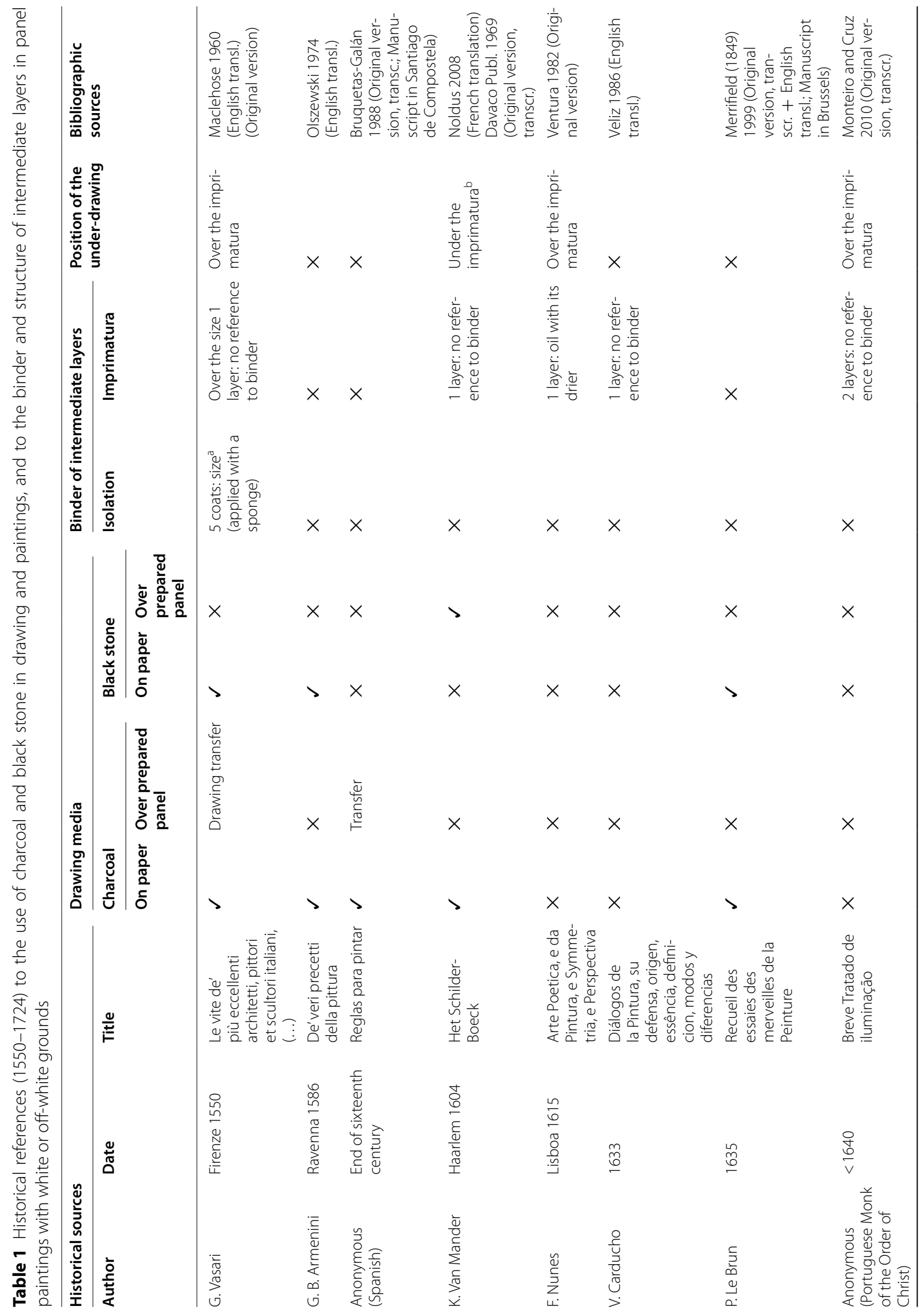




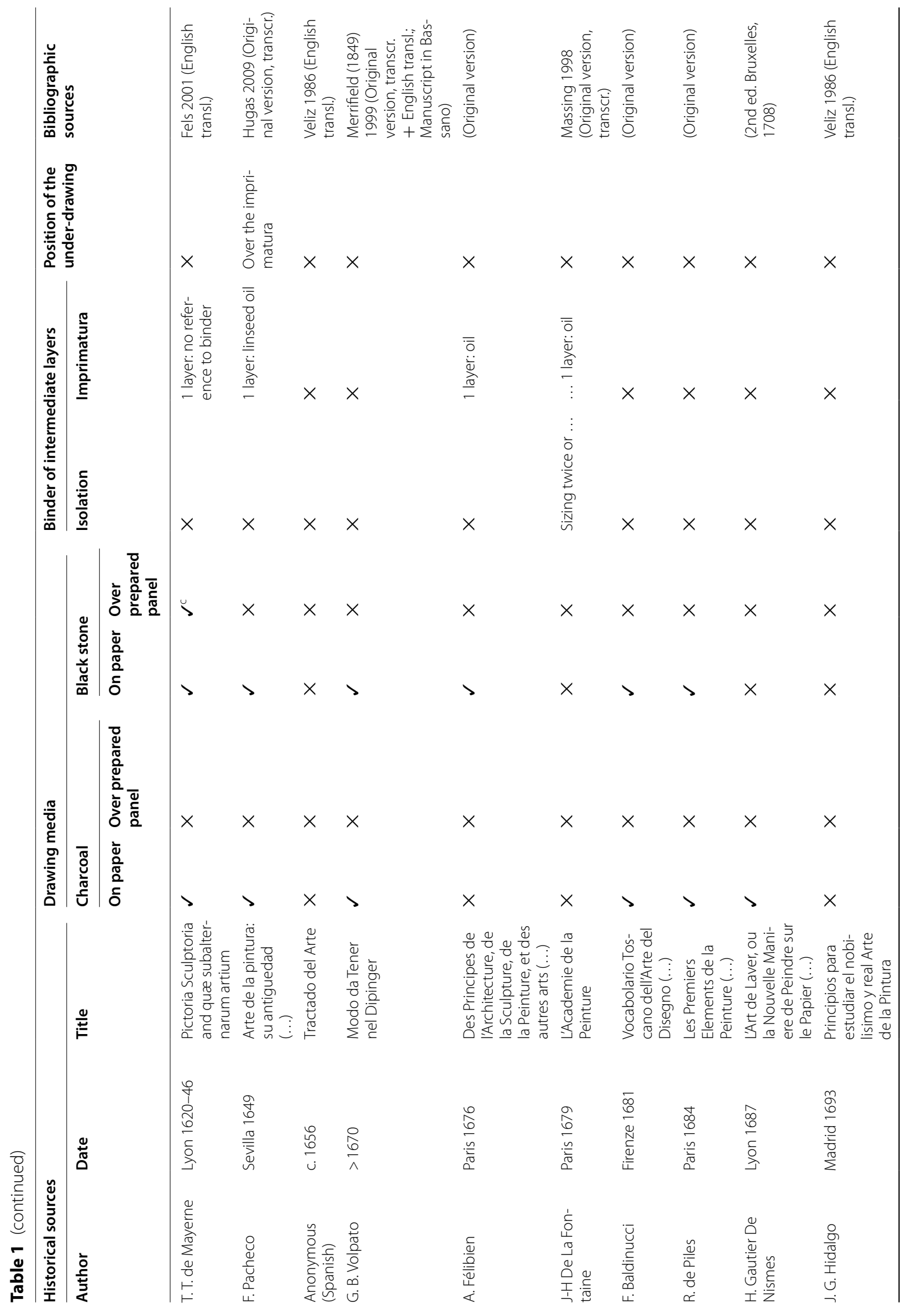




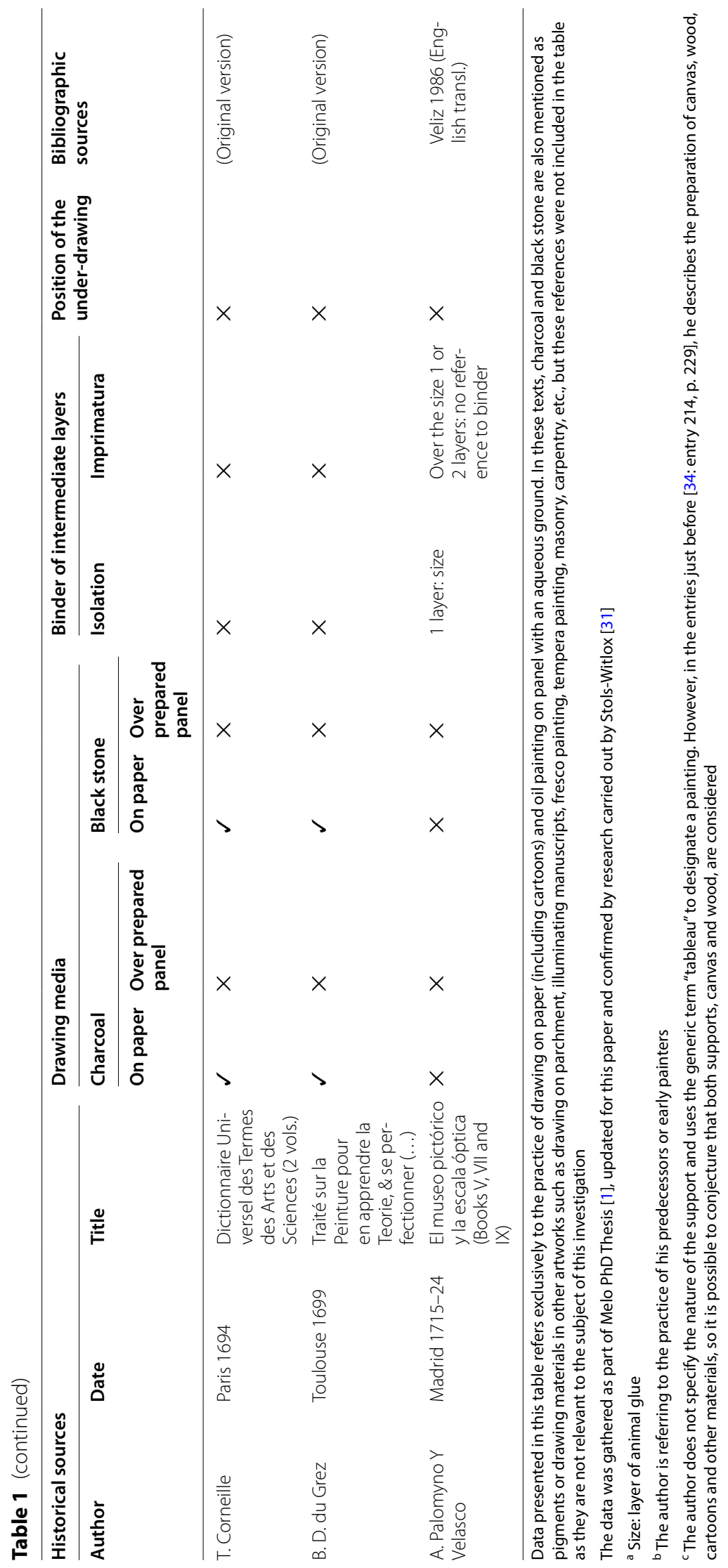


describing techniques of his predecessors, not of his own time) (Table 1).

\section{Materials and methods Analytical methods}

Infrared reflectography (IRR) was recorded using a highresolution Osiris ${ }^{\circledR}$ camera, equipped with an InGaAs sensor sensitive to infrared radiation between 900 and $1700 \mathrm{~nm}$ and an internal Schott RG850 filter that blocks radiation under $850 \mathrm{~nm}$. The lens was kept at a f/11 relative aperture.

Paint samples collected in areas where underdrawing had been previously detected using infrared examination, were embedded in an epoxy resin (Struers SpeciFix 40), polished in cross-section and studied with optical microscopy $(\mathrm{OM})$ in reflection mode, under visible (OMVis) and ultraviolet radiation (OM-UV, excitation filter BP 340-380, dichromatic mirror and suppression filter of Lp425 size), using a Leica DM2500 microscope. Digital images were taken with a Leica DFC290HD digital camera. Cross-sections mounted and examined as above were also made with samples collected from a selection of reconstruction panels, 9 years after their preparation. Details of the reconstructions were photographed in a Stereo Leica M205C binocular microscope coupled with a Leica DFC295 camera and external illumination.

Cross-sections from the Francisco João paintings were analysed with scanning electron microscopy with energy dispersive X-ray spectrometry (SEM-EDX) on a variable pressure scanning electron microscope Hitachi $3700 \mathrm{~N}$, operated at $20 \mathrm{kV}$, with a BRUKER Contact 200 EDS detector.

Micro-samples (not embedded) from these paintings were analysed with Fourier transform infrared microspectroscopy ( $\mu$-FTIR) in a previous paper and the results regarding the preparatory system are discussed in the context of the present investigation [48].

\section{Reconstructions: materials and procedures}

Materials and suppliers are listed in Additional file 1.

\section{Support}

Commercially prepared plywood panels $(30 \times 20 \mathrm{~cm})$ were sized with a $10 \%$ solution of rabbit-skin glue in water applied warm $\left(\sim 40{ }^{\circ} \mathrm{C}\right)$ with a bristle brush. Five to seven layers of anhydrite (dead-burnt gypsum) mixed in the $10 \%$ animal glue solution were applied with a bristle brush over the sized panel to create the ground layer. After a minimum drying period of 30 days, the surface was polished with 100-grit dry-wall sanding screen, followed by 240 -grit sandpaper.

\section{Intermediate layers}

A selection of different isolation and imprimatura layers were applied over the ground. Their application followed the structure found in the Francisco João paintings (and others attributed to this Portuguese Master). The oil-based isolation and imprimatura layers were applied either directly over the ground or over a ground which had first been sealed with the animal glue (Fig. 2). Twenty-four panels were prepared and the results of the performance and appearance of the reconstructed underdrawing are presented in Additional file 2.

To reduce the number of variables (e.g., oil processing with a variety of different driers, or emulsion or resinbased materials ${ }^{1}$ ) the choice of the binders was reduced to four materials: rabbit-skin glue; two untreated linseed oils (one commercially supplied by Kremer-Pigmente: ref. 73020, the other extracted from linseeds direct: HART oil ${ }^{2}$ ); and a heat-bodied drying oil prepared from the HART oil with heat and the addition of lead driers (Table 2, Additional file 1). A 50-50 solution of the untreated HART oil and heat-bodied HART oil was also included.

When the investigation began, a commercial linseed oil sourced from Kremer-Pigmente was used for the reconstructions. Information on this product indicated that it was "cold pressed", came from Sweden and was pressed from unroasted seeds and filtered [49]. HART linseed oil was made available as the investigation progressed [50]. The precise nature of this oil is known: the oil was extracted in a purpose built stainless steel laboratory oil press from a single lot of Sofie linseeds purchased in the Netherlands (Additional file 1). This oil had been allowed to stand in a glass jar for a minimum of ten weeks before use, but was otherwise untreated. Throughout this paper, for the sake of simplicity, the commercial linseed oil is referred to as "cold pressed" whereas the HART project linseed is referred to as "untreated oil" and "drying oil" respectively.

Oil and animal glue binders of similar nature as the above have been identified through chemical analyses in the intermediate layers of sixteenth century paintings $[15,19,33,51-54]$ and are mentioned in historical documents [29, 45, 47, 55-57] (Table 1). The oil binders were used pure and were also mixed with a little turpentine (Table 2).

Paint for the imprimatura layers was prepared by hand grinding powdered lead white pigment in the linseed oils

\footnotetext{
${ }^{1}$ Emulsion and resin-based intermediate layers are also mentioned in historical technical sources $[16,40]$, but were beyond the scope of this research.

2 The HART linseed oil was kindly supplied to this project by Leslie Carlyle (See Additional file 1).
} 
a

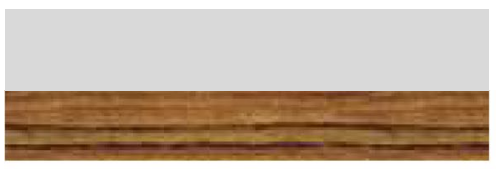

b

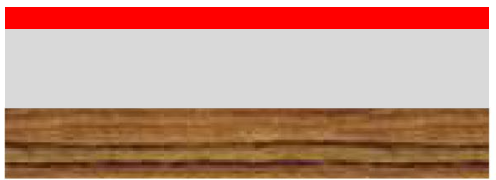

C
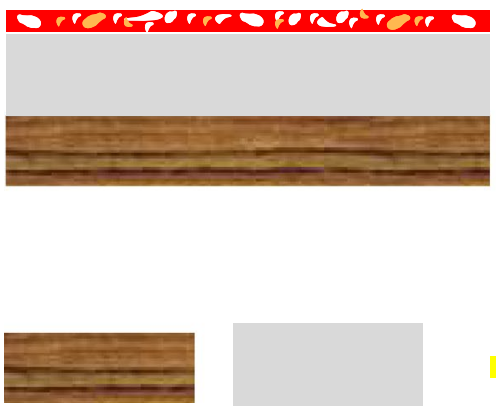

Support

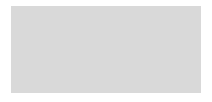

Ground

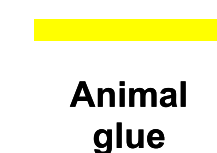

$a^{\prime}$

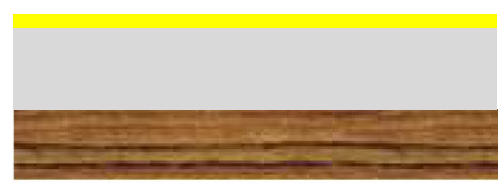

b'

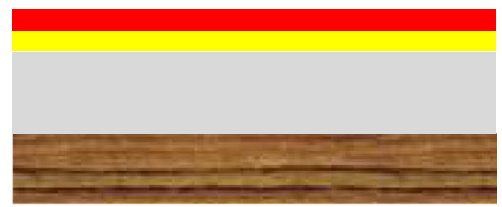

$c^{\prime}$
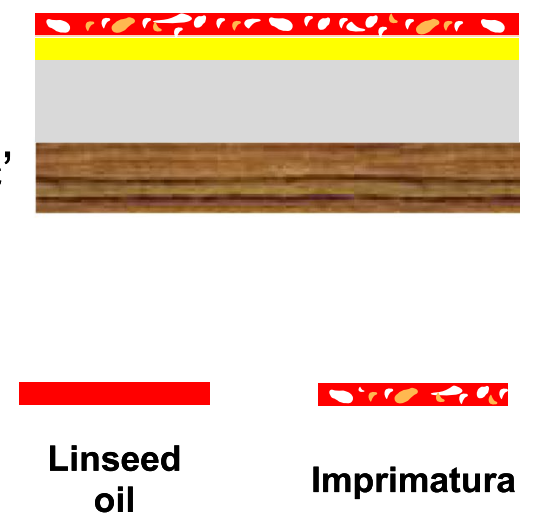

Fig. 2 Structure of the preparatory layers in the reconstructions. The nature and composition of the intermediate layers (animal glue, linseed oil and imprimatura) are specified in Table 2. OHPM \& AJC, HERCULES Lab—U. Évora, Portugal

(above) on a glass slab with a glass muller, then adding a small amount of minium to imitate the imprimaturas found in some of Francisco João's paintings [1]. The imprimatura paints were prepared by first grinding the opaque paints above to a fluid consistency (Additional file $2 / \mathrm{P} 13, \mathrm{P} 14$ ), then adding additional oil to increase the proportion of binder to pigment and achieve even more translucency (Additional file 2/P13a, P14a). The lead white and minium pigments were from La Droguerie Le Lion in Brussels and their composition was confirmed by SEM-EDX analysis of the dry powders.

\section{Underdrawing media}

Charcoal, untreated and oiled, and black stone were used as underdrawing materials.

Twigs of willow charcoal supplied by Coates (England) were chosen for the reconstructions. The softwood from willow (Salix L.) is mentioned for making drawing sticks in various historical sources, e.g., Cennini [27: p. 82, 222], Vasari [29: p. 231], Armenini [40: p. 274], Pacheco (15641644) [47: p. 448, 451], Volpato [36: p. 752] and Corneille (1625-1709) [58: p. 193].
For each reconstruction a fresh twig of willow charcoal was used to ensure the drawing stick had not been contaminated from contact with oil-based surfaces. As with the black stone, the charcoal was used as a stick for drawing and crushed into a powder to be used for pouncing. It was also applied to the back of a sheet of paper for the transfer of lines onto the different prepared surfaces.

Without a specific reference to the nature of the "common oil" used to anoint a charcoal stick, mentioned by Volpato [36: p. 752], two different pieces of willow charcoal were each dipped overnight in a drying linseed oil (Kremer, ref. 73020) and in a non-drying olive oil (commercial, cold-pressed, Gallo-Portugal, see Additional file 1) and left to dry. Although other non-drying oils could have been considered, the olive oil, also used by Bescoby et al. in reconstructions in the context of drawing on paper [4] would have been widely available at the time in southern Europe, notably Portugal [59]. Olive oil was therefore considered as being representative of the non-drying category of oils possible to have been used. Although both 'oiled charcoals' initially worked well as drawing tools, the charcoal twig embedded in linseed 
Table 2 Binder of the intermediate layers used in the reconstructions

\begin{tabular}{|c|c|}
\hline Binder of intermediate layers & Ingredients and method of preparation \\
\hline Animal glue solution & $\begin{array}{l}10 \mathrm{~g} \text { rabbit-skin glue in plates }+90 \mathrm{ml} \text { distilled water } \\
\text { Animal glue plates immersed in water overnight. Heated in a water bath to } \\
\text { a maximum of } 40-50^{\circ} \mathrm{C}\end{array}$ \\
\hline KREMER cold-pressed linseed oil & Cold-pressed linseed oil from Sweden (Kremer, Ref. 73020) \\
\hline HART untreated linseed oil ${ }^{a}$ & $\begin{array}{l}\text { Manually cold-pressed linseed oil (Sofie Linseeds, Netherlands) } \\
\text { Oil pressed on the } 05.06 .2019 \text {. No treatment to eliminate sediment or } \\
\text { mucilage. Left to settle, decanted oil used (See Additional file 1) }\end{array}$ \\
\hline \multirow[t]{6}{*}{ HART drying linseed oil ${ }^{a}$} & $\begin{array}{l}250 \mathrm{ml} \text { manually cold-pressed linseed oil (Sofie Linseeds, Nether- } \\
\text { lands) + } 12.5 \mathrm{~g} \text { minium }+12.5 \mathrm{~g} \text { litharge }\end{array}$ \\
\hline & $\begin{array}{l}\text { Oil prepared according to Recipe P1P327 from the Winsor \& Newton } \\
\text { Archive Database (17. 06. 2019) }\end{array}$ \\
\hline & Dry powders: c. $10 \%$ of the solution \\
\hline & The dry powders were mixed together and added to the oil \\
\hline & $\begin{array}{l}\text { The mixture was heated to } 93.3^{\circ} \mathrm{C}\left(200^{\circ} \mathrm{F}\right) \text { and stirred continuously for } 5 \mathrm{~h} \\
35 \mathrm{~min}\end{array}$ \\
\hline & Left to cool, decanted oil used (See Additional file 1) \\
\hline HART untreated linseed oil + HART drying linseed oil (1/1) & Equal parts of each oil were manually mixed in a glass jar \\
\hline \multirow[t]{4}{*}{ KREMER cold-pressed linseed oil + turpentine } & $\begin{array}{l}\text { The brush was first dipped in turpentine and only then slightly mixed in a } \\
\text { glazed ceramic bowl containing the oil binder ( c. 30-50\% turpentine) }\end{array}$ \\
\hline & $\begin{array}{l}\text { For the imprimatura paints, the brush was dipped in turpentine and } \\
\text { directly mixed with the paint on the glass slab }\end{array}$ \\
\hline & The paint became quite liquid ( c. 30-50\% turpentine) \\
\hline & The percentage of turpentine was assessed by eye \\
\hline \multirow[t]{4}{*}{ HART untreated linseed oil + HART drying linseed oil (1/1) + turpentine } & $\begin{array}{l}\text { The brush was first dipped in turpentine and only then slightly mixed in a } \\
\text { glazed ceramic bowl containing the oil binder ( c. } 30-50 \% \text { turpentine) }\end{array}$ \\
\hline & $\begin{array}{l}\text { For the imprimatura paints, the brush was dipped in turpentine and } \\
\text { directly mixed with the paint on the glass slab }\end{array}$ \\
\hline & The paint became quite liquid ( c. 30-50\% turpentine) \\
\hline & The percentage of turpentine was assessed by eye \\
\hline
\end{tabular}

a Oils prepared and kindly provided by Dr. Leslie Carlyle and Raquel Marques from Nova University, Lisbon, Portugal

oil,- - a material subject to chemical curing (drying by oxidation)-became harder and more difficult to draw with within three to four weeks of it being soaked in the oil. As olive oil is non-drying, it doesn't harden upon exposure to air. The charcoal dipped in olive oil was selected for all reconstructions as it remained viable without further dipping for a period that extended up to one year.

For reconstruction purposes, a modern natural black stone from France, supplied by Kremer Pigmente, in Germany, was used since the actual identity of that used in the sixteenth century and particularly in the Francisco João paintings could not be determined. The Kremer black stone was used directly as a drawing stick and also as a pouncing powder by crushing it in a granite mortar. As research was ongoing, a different black stone, known as 'ampelite from Crozon', in Bretagne, was obtained and tested as a drawing material in reconstructions. ${ }^{3}$ The Crozon black stone, which was supplied as a thin sheet

\footnotetext{
${ }^{3}$ The Crozon black stone was kindly provided by Mr. Jean-Yves Cordier.
}

(a slate) exhibited a lighter grey colour than the Kremer black stone.

\section{Underdrawing process}

The dry drawing materials were applied in sets of lines which were drawn free-hand, traced and pounced over the grounds on the test panels (Fig. 3). For the pounced lines, two different sheets of a modern translucent tracing paper, used out of convenience, were pricked with a needle and the reverse sanded with sandpaper. Following the experiments by Currie and Ghys [19], two small cloth stumps were created with soft cotton rags inside. The base of each stump was dipped in the black powdercharcoal or black stone-and then passed over the paper sheet with the pricked dots, creating a neat/clean row of pounced black dots over the surface.

To reconstruct an underdrawing, a detail of the head of one of the apostles in the background from the Sousel altarpiece $(8 \times 14 \mathrm{~cm})$ was chosen (Fig. 3$)$. The underdrawing was first copied 1:1 onto a sheet of tracing paper from a full-size IR image. The outline was then traced 

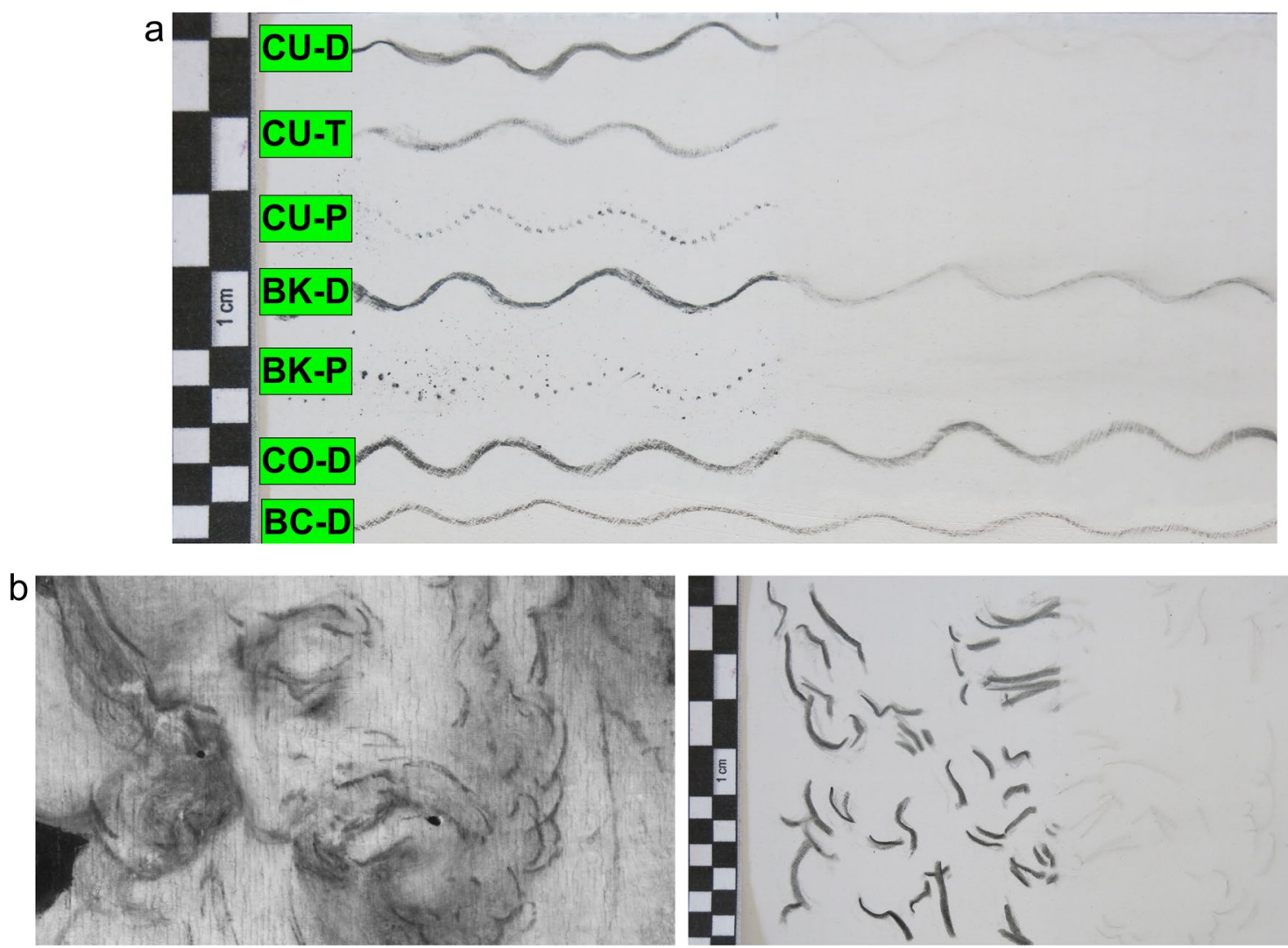

Fig. 3 a Reconstruction with lines made over an untreated gesso ground with the following materials: charcoal, untreated drawn (CU-D), traced (CU-T) and pounced (CU-P); black stone from Kremer drawn (BK-D) and pounced (BK-P); charcoal, oiled, drawn (CO-D) and black stone from Crozon drawn (BC-D). The right half of the panel was brushed with a feather to determine the removability of the lines. $\mathbf{b}$ IR reflectogram assembly of a detail from the Sousel altarpiece. c Underdrawing reconstruction of detail (b) made with untreated charcoal drawn directly over the gesso ground. On the right side, a feather was brushed over the surface, as in a, to eliminate unbound particles. All images @HPM, HERCULES Lab-U. Évora, Portugal

with charcoal on the backside of the sheet and transferred onto the prepared surfaces with a small wooden stick. The final drawing on the prepared panel was then made free-hand over these traced lines.

The underdrawing was applied in a sequence of 15,30 and 60 days after the application of the intermediate layers for all binders with the exception of those containing the HART heat-bodied oil. In the latter case, because of the shorter drying time, the underdrawing was applied after 10, 15 and 30 days. To test the behaviour and permanence of the drawings, half of each drawn surface was brushed with a feather, using the required force and number of passages that, in each case, would guarantee the elimination of the maximum amount of unbound particles (Fig. 3).

\section{Results}

Preparatory layers and underdrawing in the paintings by Francisco João

SEM-EDX and $\mu$-FTIR analysis of micro-samples from all three altarpieces revealed that the panels had been prepared with a single ground layer of gesso grosso, mainly composed of anhydrite with small amounts of calcium sulphate dihydrate bound in animal glue [48]. Infrared spectra of all ground samples detected, besides proteins, free fatty acids related to the ageing of oil [48]. The latter are thought to have resulted from the absorption of the oil-based binder used in the layers above. In the panels from the altarpiece of São Francisco, a binder-rich pigmented imprimatura-oil-based according to $\mu$-FTIR analysis-containing occasional particles of vermilion could be clearly distinguished over the ground as a separate layer with a thickness of $10-20 \mu \mathrm{m}$ (Fig. 4).

In the paintings from the Machede and Sousel altarpieces, no separate intermediate layer could be detected 


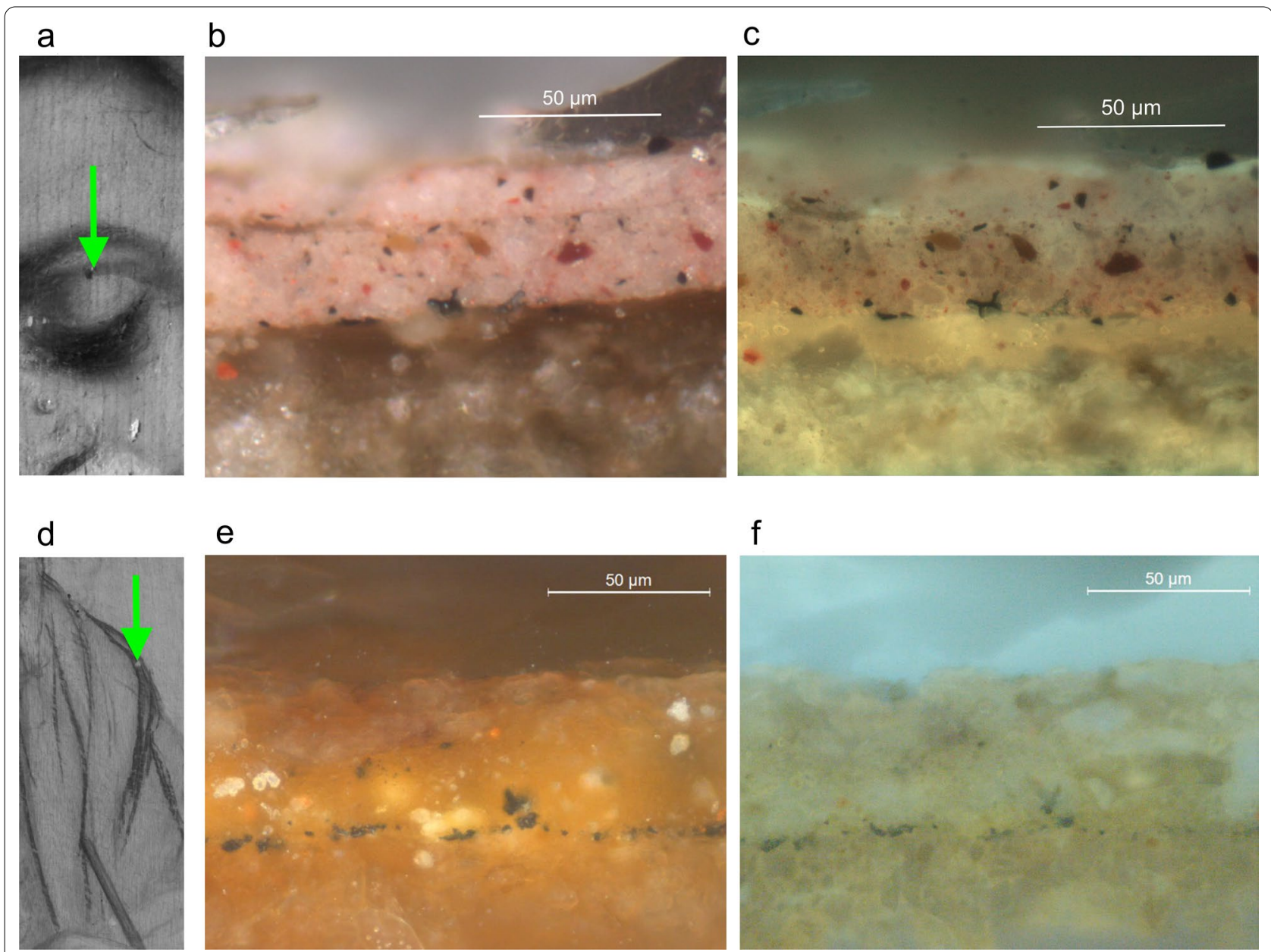

Fig. 4 Infrared details of the underdrawing from paintings of the São Francisco (a) and Sousel (d) altarpieces with the location (green arrow) of the samples viewed in cross-section in the optical microscope under incident light (OM-Vis) (b, e) and ultraviolet radiation (OM-UV) (c, f). All images OHPM, HERCULES Lab-U. Évora, Portugal

and the oil-based organic material detected by $\mu$-FTIR analysis in the upper part of the ground could have either originated from an isolation layer applied to seal the ground or from the binder in the paint layers above (Figs. 4, 5).

The black particles associated with underdrawing differed in appearance according to the altarpieces when examined in cross-section under the microscope. Sparse elongated particles with a splintery shape typical of charcoal $[3,4,15,17]$ were found aligned horizontally over the imprimatura, in the São Francisco paintings (Fig. 4). Particles with a more heterogeneous shape, mostly rounded but sometimes angular, lying closer together were seen creating a thin dotted black line in the binder-rich interface between the ground and paint layers in the panels from Machede and Sousel (Figs. 4, 5).

Despite this difference in morphology, all particles analysed with SEM-EDX were mainly composed of carbon $(\mathrm{C})$, calcium $(\mathrm{Ca})$, sulphur $(\mathrm{S})$ and lead $(\mathrm{Pb})$. Except for carbon, the other elements are likely associated with the ground $(\mathrm{Ca}, \mathrm{S})$ and the paint layers $(\mathrm{Pb})$. Some differences in composition were noted in terms of the trace elements present in concentrations below $0.9 \mathrm{wt} . \%$ - such as potassium $(\mathrm{K})$, sodium $(\mathrm{Na})$, magnesium $(\mathrm{Mg})$, silicon $(\mathrm{Si})$, aluminium $(\mathrm{Al})$ and iron $(\mathrm{Fe})(\mathrm{Table} 3)$. Elements characteristic of the associated clay minerals present in black stone, namely $\mathrm{Al}, \mathrm{Si}$ and $\mathrm{Fe}$, were found in too low a concentration to enable a positive identification of this mineral. Given the small size of the particles and the 


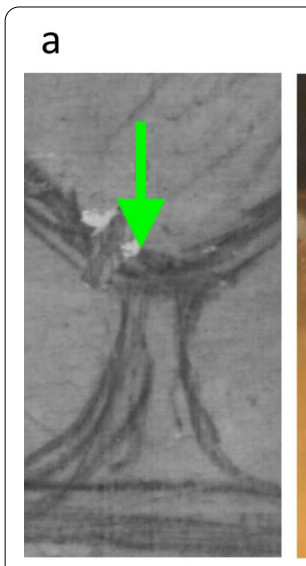

b

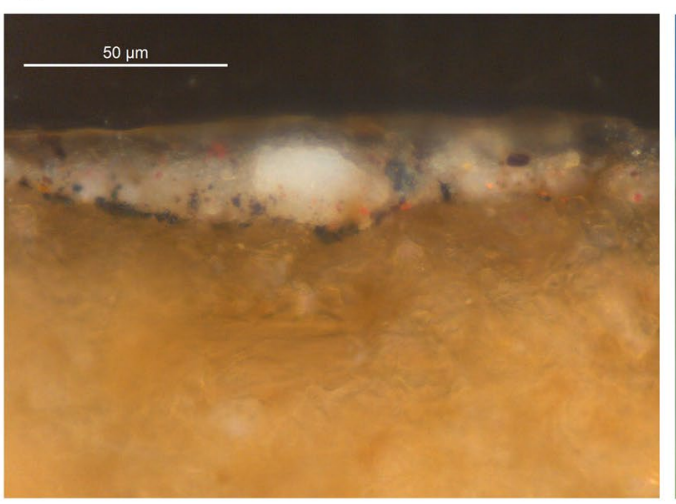

C

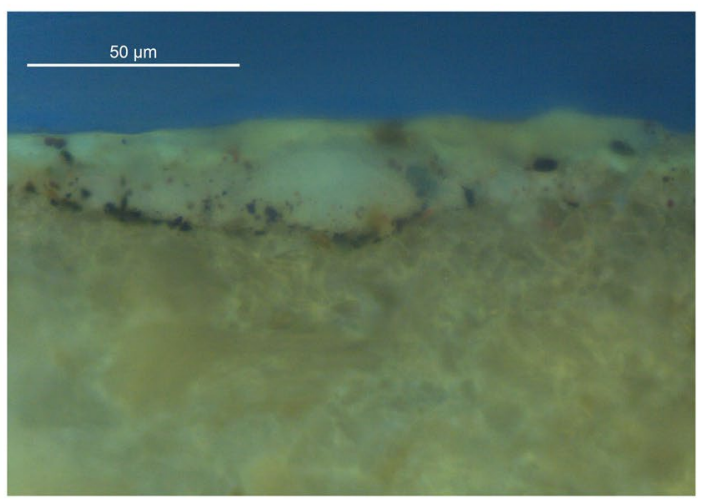

e

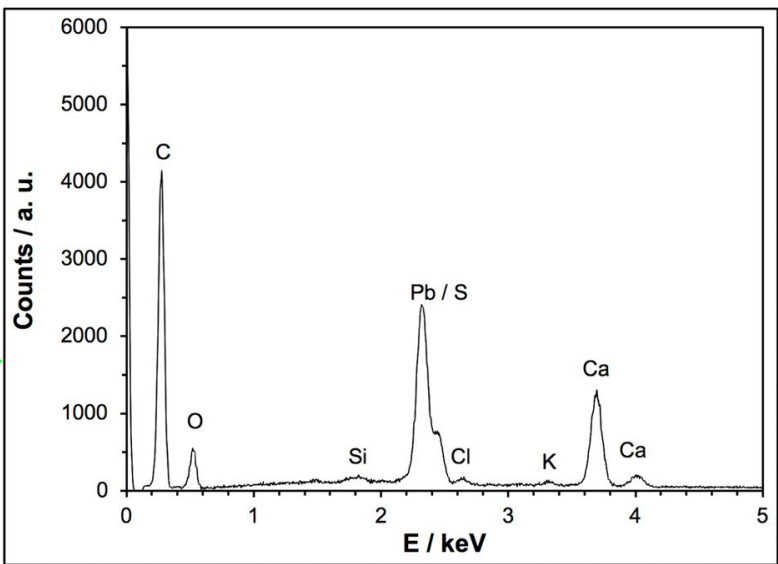

SE MAG: $6500 \times$ HV: $20.0 \mathrm{kV}$ WD: $9.9 \mathrm{~mm}$

d
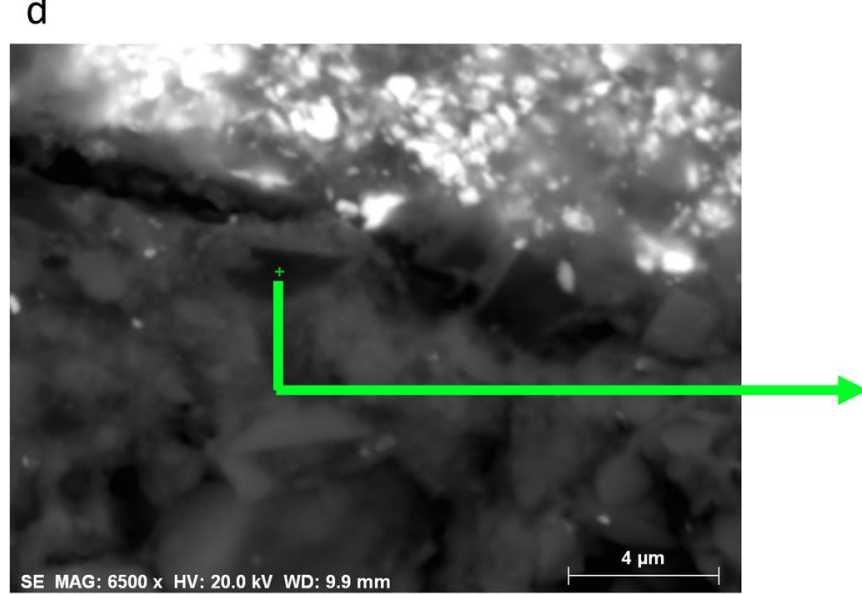

Fig. 5 Infrared detail of the underdrawing from a painting of the Machede (a) altarpiece with the location (green arrow) of the sample viewed in cross-section in the optical microscope under incident light (OM-Vis) (b) and ultraviolet radiation (OM-UV) (c); SEM backscatter image of a detail of the same sample with the location (green arrow) of an underdrawing particle (d) and SEM-EDX spectrum (e) of particle shown in (d). All images OHPM \& SV, HERCULES Lab—U. Évora, Portugal

Table 3 SEM-EDX elemental analysis of black underdrawing particles

\begin{tabular}{ll}
\hline Altarpiece & $\begin{array}{l}\text { Elements identified in the } \\
\text { underdrawing particles }\end{array}$ \\
\hline S. Francisco & $\mathrm{C}, \mathrm{Ca}, \mathrm{S}, \mathrm{Pb}(\mathrm{K}, \mathrm{Na}, \mathrm{Mg}, \mathrm{Si}, \mathrm{Al})$ \\
Machede & $\mathrm{C}, \mathrm{Ca}, \mathrm{S}, \mathrm{Pb}(\mathrm{K}, \mathrm{Fe}, \mathrm{Si}, \mathrm{Al})$ \\
Sousel & $\mathrm{C}, \mathrm{Ca}, \mathrm{S}, \mathrm{Pb}(\mathrm{Na}, \mathrm{Mg}, \mathrm{Si}, \mathrm{Al})$ \\
\hline
\end{tabular}

Elements with a concentration below $0.9 \mathrm{wt} . \%$ are presented in parentheses

difficulty in analysing carbon-based underdrawing particles, SEM-EDX elemental analysis was not sufficient to identify the specific material used for the underdrawing. ${ }^{4}$ Furthermore, the use of fabricated chalks is also conceivable $[5,30]$. As an example, a recipe for "Making chalks in all colours for painting on paper" by De Mayerne (1620-1646) contains a mixture of plaster soaked in black ink, black stone and smoke black [34: p. 264], a combination that would render their identification impossible.
In conclusion, $\mathrm{OM}$ and $\mu$-FTIR analysis strongly suggests the use of a charcoal underdrawing on top of an oil-based imprimatura in the paintings of São Francisco. Results are inconclusive regarding the identification of the carbon-based underdrawing material and structure of the preparatory system in all other paintings. ${ }^{4}$

\section{Reconstructions of preparatory layers and underdrawings}

The results presented in Additional file 2 are summarised below.

\section{Intermediate layers}

Oil or glue isolation layers applied directly over the ground were partially absorbed by the gesso and did not appear to form a distinct film at the surface. Cross-sections from reconstructions examined in OM confirmed that oil applied directly was absorbed into the gesso, whereas a layer of glue applied to the gesso first prevented 

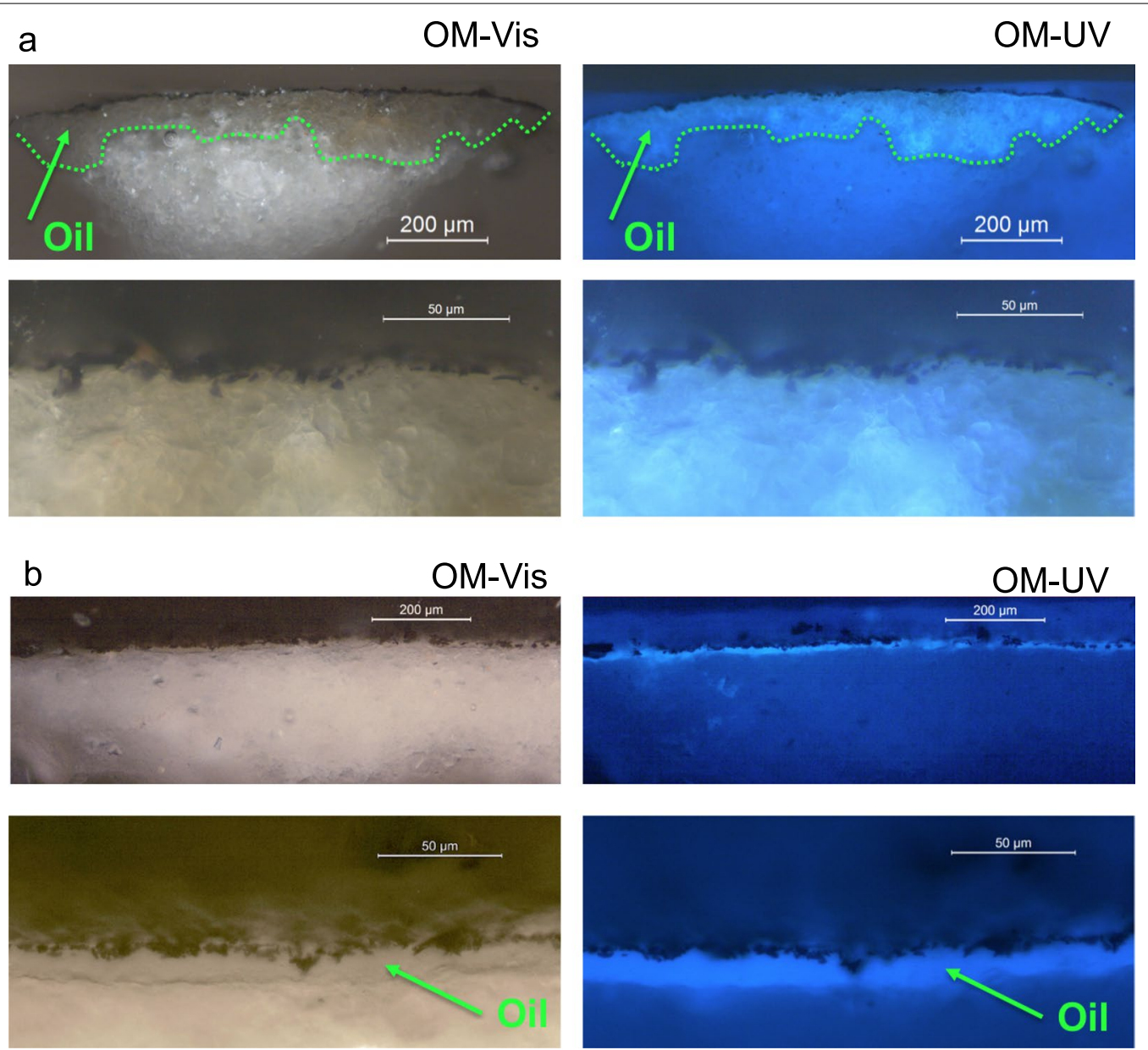

Fig. 6 Cross sections of reconstructions with charcoal underdrawing viewed at different magnifications in the optical microscope under incident light (OM-Vis) and ultraviolet radiation (OM-UV). a Ground covered with a cold-pressed oil isolation layer: penetration of the oil is clearly visible. $\mathbf{b}$ Ground first sealed with animal glue and then covered with cold-pressed linseed oil isolation layer: no oil penetration into the gesso is evident. See Additional file 1 for information on the materials used. All images OHPM, HERCULES Lab—U. Évora, Portugal

the subsequent layer of oil from being absorbed by the ground (Fig. 6).

\section{Underdrawing materials}

The appearance of drawing lines made with the modern dry materials under study, even when not covered by a paint layer, confirms that when examined by the naked eye and with higher magnifications in a binocular microscope, it can be challenging to distinguish each specific material (Fig. 7).

\section{Charcoal}

Charcoal drawn directly on top of a gesso ground or a glue isolation layer was easily dusted away by a feather, leaving only some faint and partial lines (Fig. 3).

In contrast, when drawn on top of any oil-based isolation layer, the charcoal underdrawing lines, although with some loss of unbound particles, remained fixed whether the oil layer had been allowed to dry 10, 15, 30 or 60 days (Figs. 8, 9, Additional file 2). With increased drying time for the oil, a greater amount of charcoal could be dusted away leaving the charcoal drawing lighter in tone yet visible (Figs. 8, 9). When charcoal was applied over an oilbound imprimatura layer, there was more loss of material and the remaining lines were more faint than those applied to isolation layers consisting of oil only (Fig. 10). After 60 days, the charcoal lines over the imprimatura layer would be almost completely lost (Fig. 10/P13).

Interestingly, when the oil-based isolation layers or imprimatura layers had been applied over a gesso sealed with animal glue, the degree that the charcoal was fixed into the surface was greater (Figs. 8, 9 / P4, P10, P12a). Similarly, the imprimatura layers with a higher proportion of binder (Additional file 2/P13a, P14a) were more effective in fixing the charcoal particles than those with 

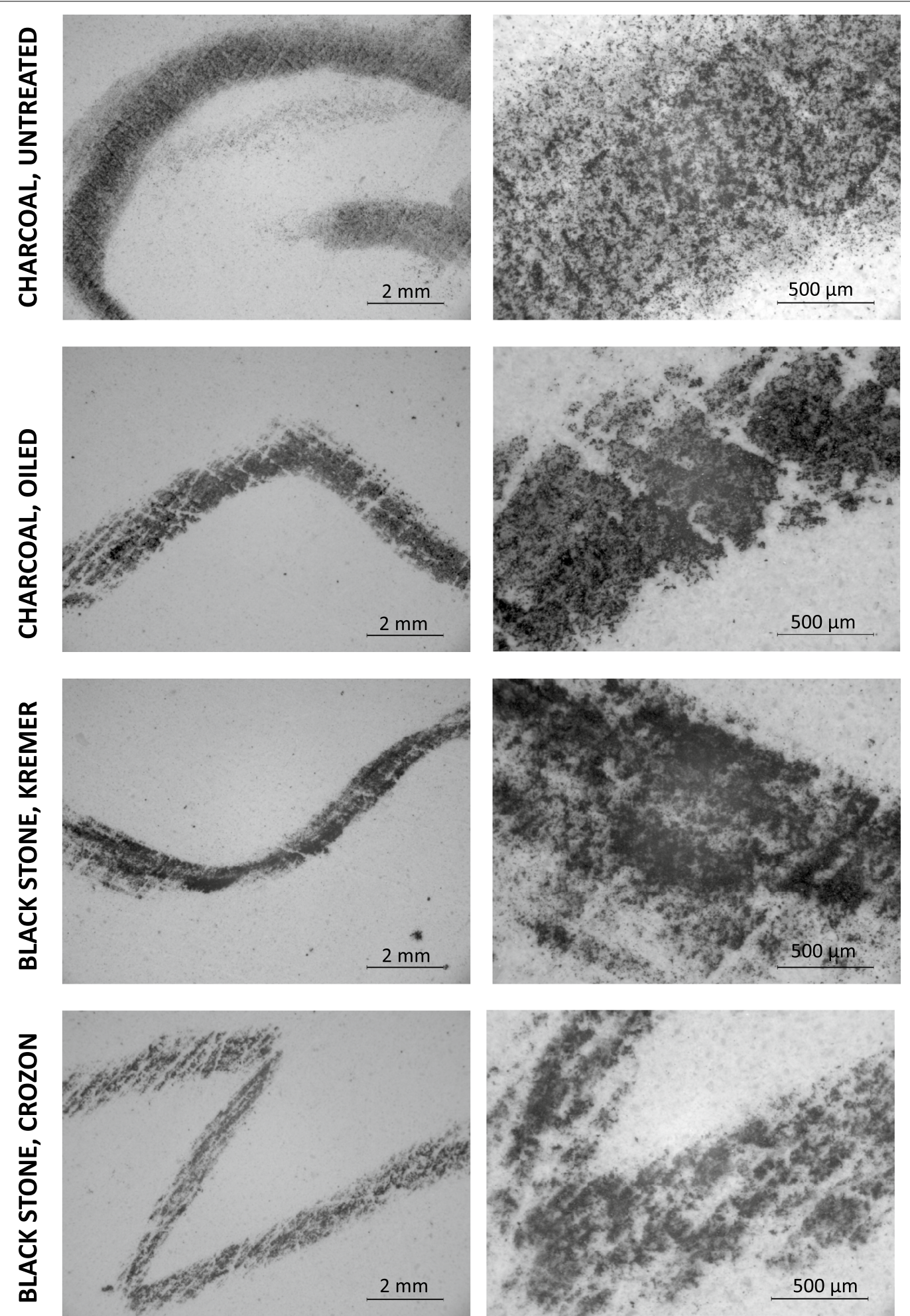

Fig. 7 Details of drawing made with the modern dry media under study over an untreated gesso ground, viewed under the binocular microscope with $\times 1.25$ (left) and × 6.3 (right) magnifications. All images OHPM, HERCULES Lab—U. Évora, Portugal 

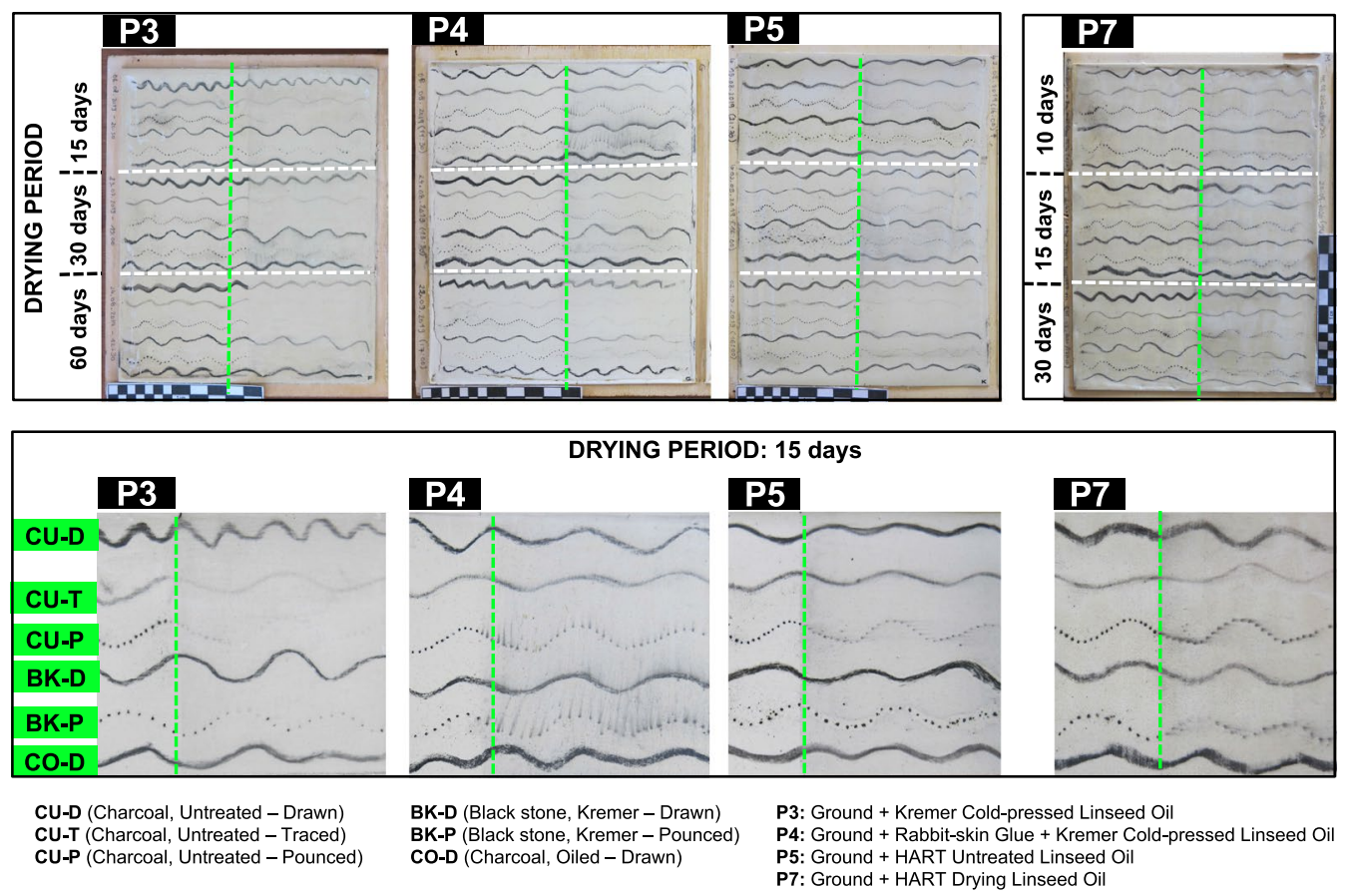

Fig. 8 Reconstructions with the gesso ground covered with different isolation layers. In the upper row, the drawings were executed 15, 30 and 60 days after the drying of the prepared surface, except for Panel 7 (P7) where the HART drying linseed oil was used and tests were therefore performed 10, 15 and 30 days after the application of the final isolation. In the lower row, details of the reconstructions of the upper row when the drawing was done 15 days after preparing the panel surface. Each panel was brushed with a feather to the right of the green line. to determine the removability of the lines. All images OHPM, HERCULES Lab-U. Évora, Portugal

a higher pigment concentration (Additional file 2/P13, P14). The addition of a little turpentine to the oil in the isolation and imprimatura layers had no effect on the degree of fixing of the charcoal lines (Fig. 9/P11, P12a).

The source of the linseed oil played a role in whether pounced and traced charcoal lines became fixed. When the transfer was done over isolation and imprimatura layers prepared with Kremer oil these charcoal lines could be dusted off (in accordance with reconstructions by Currie and Ghys [19], Fig. 8/P3). However, when HART untreated and drying oils were used, the pounced and traced lines retained their shape, including the pouncing dots (over oils dried 10, 15 and, in some cases, 30 days, Fig. 8/P5, P7). Unknown parameters related to the properties and composition of the two linseed oil sources appear to have played a part in the different behaviour observed, an issue that requires further research. The composition of the linseed oil from the Sofie seed lot may have resulted in a slower drying time and hence remained viscous for a longer period making it more efficient in fixing the charcoal material.

\section{Oiled charcoal}

When drawn over the ground surface, the oiled charcoal resembled the Kremer black stone (Fig. 7). In comparison to charcoal alone, the oiled charcoal lines had a deeper black tonality and appeared more compact, with light streaks in the ground devoid of the black powdery material observed when using untreated charcoal (Fig. 7).

The oiled charcoal was extremely easy and agreeable to draw with on all of the surfaces prepared. After passing over them with a feather, the lines were not smudged, conforming to recent observations by Currie et al. [26] (Figs. 3, 8). When used directly over the untreated gesso ground, the oil from the charcoal did not stain by producing oil halos around the lines (Figs. 3, 7). It was only necessary to oil the charcoal stick once to create such an effective drawing tool, and even after keeping for a full year, its properties remained the same.

\section{Black stone}

Kremer's black stone was variable in terms of its hardness making it difficult to draw with. The softer parts often left unbound particles that had to be brushed away in order to avoid staining a subsequent paint layer (Figs. 3, 8). This tendency had been noted by De Mayerne: "it is nevertheless necessary wipe the picture clean before painting, so that the mentioned chalk does not come into contact with the paints and dirty them" [34: p. 230]. 

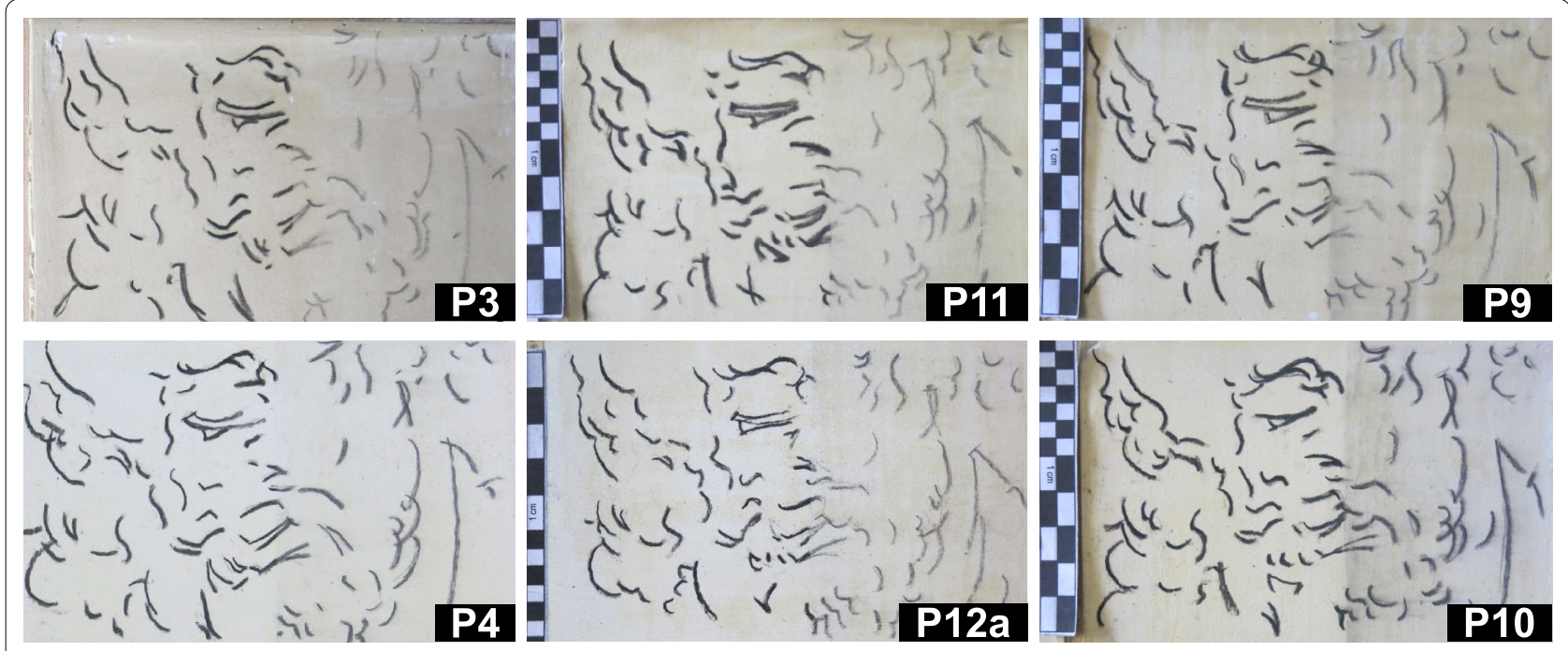

$$
\begin{aligned}
& \text { P3: Ground } \\
& \text { + Kremer Cold-pressed Linseed Oil } \\
& \text { P4: Ground + Rabbit-skin Glue } \\
& \text { + Kremer Cold-pressed Linseed Oil }
\end{aligned}
$$

P11:

+ Kremer Cold-pressed Linseed Oil Turpentine

P12a: Ground + Rabbit-skin Glue + Kremer Cold-pressed Linseed Oil / Turpentine
P9: Ground

+ HART Untreated Linseed Oil / HART Drying Linseed Oil (1/1)

P10: Ground + Rabbit-skin Glue + HART Untreated Linseed Oil / HART Drying Linseed Oil (1/1)

Fig. 9 Reconstructions of charcoal underdrawing: (top) over linseed oil applied directly over the gesso ground, (bottom) over linseed oil applied over a gesso ground which was first sealed with an animal glue layer. The oil layers had been dried for 30 days before underdrawings were applied. The right half of each panel was brushed with a feather to determine the removability of the lines. All images OHPM, HERCULES Lab—U. Évora, Portugal

In this regard, the Crozon black stone was harder, less friable and drew finer lines of a grey colour, quite different from the Kremer material (Figs. 3, 7). Drawings made with both black stones remained fixed on all surfaces, including the untreated gesso. However, it was difficult and, in the case of the Crozon black stone, sometimes impossible, to create a visible mark over the imprimatura prepared with lead white and minium, due to its rubbery surface and the pressure required to create a mark (Fig. 10/P15). The difficulty in using the Kremer black stone had been noted before [33].

Pounced dots of black stone on untreated gesso, or with a glue isolation or oil-bound imprimatura were easily erased; identical behaviour to that of pounced charcoal (Figs. 3, 8). However, black stone pouncing dust showed a higher resistance to smudging than charcoal dust (Fig. 8). Pounced dots of black stone applied over a 15 day-old oil-based layer invariably remained visible on the surface (Fig. 8). It should be noted that Kremer black stone was difficult to use as a pouncing dust. When crushed into a powder, the particles tended to clump up and form plates of agglomerated material: not a light dust. This restricted its passage through the pouncing holes of the transfer paper.

\section{Summary of observations}

1. Charcoal lines remained fixed when drawn over oil layers. There was always a partial loss of the charcoal but the underdrawing lines retained their shape. The shape of the underdrawing lines was particularly apparent when the oil layer had been applied over a sealing coat of glue. The use of oil treated with driers, or pure oil with the addition of a little turpentine did not considerably affect the degree to which the charcoal lines became fixed. Similarly, charcoal lines over the oil-bound imprimatura layer remained fixed, particularly where the imprimatura layer had a higher oil content.

2. Oiled charcoal is a versatile and extremely easy material to use. The lines are of a deep black tonality and while they can exhibit the friable gritty appearance of charcoal, oiled charcoal lines do not smudge and retained their appearance on all of the ground variations.

3. Lines made with both sources of black stone were not erasable from the test surfaces. However, both were difficult to use, especially over the imprimatura layer. 


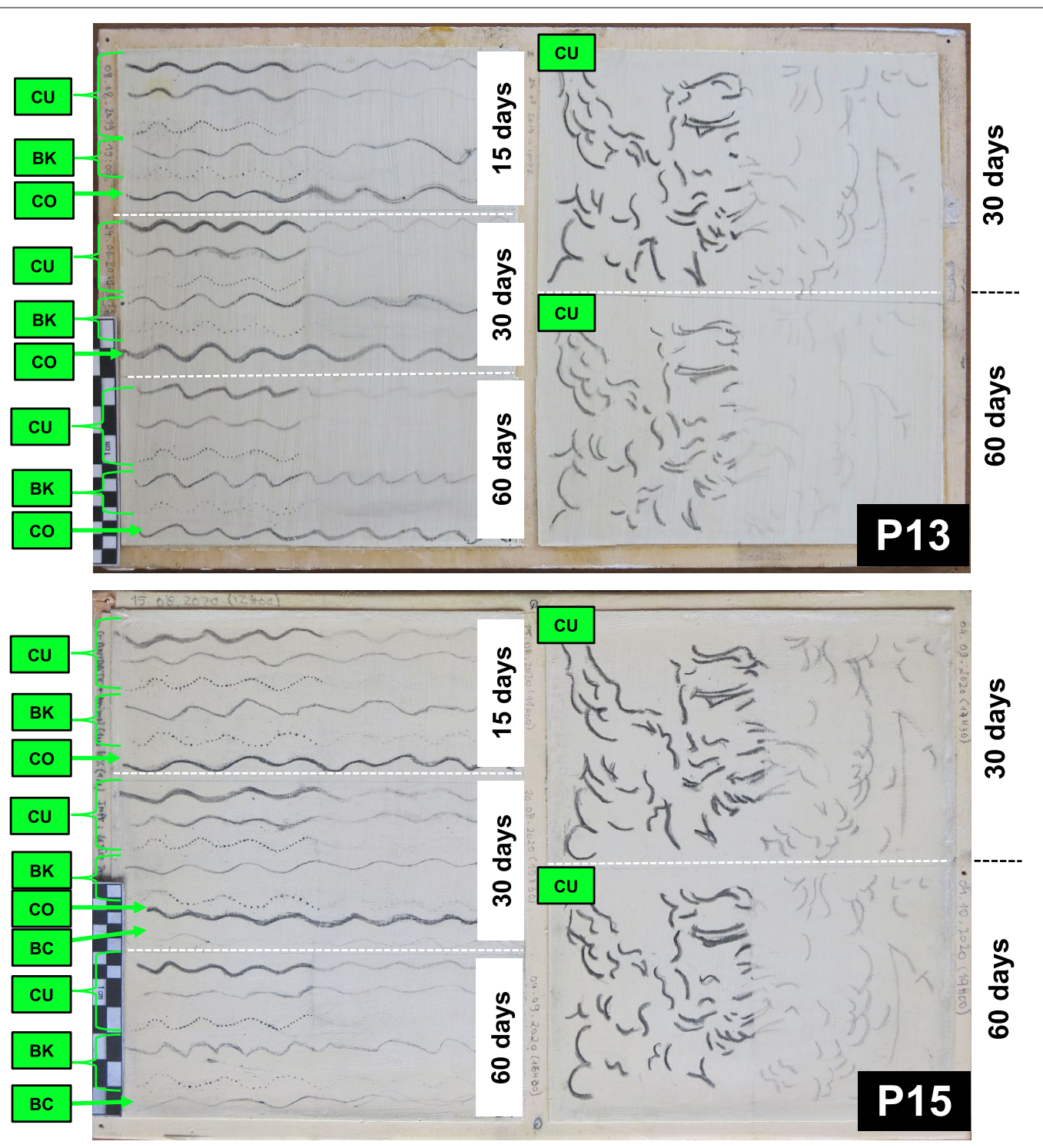

$$
\begin{aligned}
& \begin{array}{l}
\text { CU: Charcoal, Untreated } \\
\text { CO: Charcoal, Oiled }
\end{array} \quad \text { BC: Black stone, Kremer } \\
& \begin{array}{l}
\text { P13: Ground + Imprimatura } \\
\text { (Kremer Cold-pressed Linseed Oil + Lead White + Minium) }
\end{array}
\end{aligned}
$$

P15: Ground + Imprimatura

(Hart Untreated Linseed Oil / HART Drying Linseed Oil (1/1) + Lead White + Minium)

Fig. 10 Reconstructions over imprimatura layers with different underdrawing materials. The right half of each panel was brushed with a feather to determine the removability of the lines. All images OHPM, HERCULES Lab—U. Évora, Portugal

4. Pounced dots of charcoal could be erased when applied over untreated gesso or with a sealing coat of animal glue but tended to remain on the surface on top of an oil isolation layer, particularly when the gesso had first been sealed with animal glue.

5. A normally friable and easily erasable material like charcoal, although it might lose some unbound mate- 
rial at the surface, will become fixed on a ground treated with oil, even after the oil has been allowed to dry up to 3 months before the charcoal was applied and is no longer tacky to the touch.

\section{Discussion}

Previous research has shown that, on occasion, Jan Van Scorel (1495-1562) and Rubens (1577-1640) made their underdrawings with a dry medium over an imprimatura layer that was most probably not completely dry [16, 17, 60]. Cross-sections of Rubens' oil sketches revealed that black chalk particles from the underdrawing were "pressed into the possibly still soft imprimatura layer" [16, p. 83], whereas the underdrawing contours in a Lamentation by Van Scorel could be seen in raking light to be "deeply indented into the underlying layer" [17: p. 28].

The fact that pounced dots sometimes are not smudged in underdrawings had already been associated with the possibility that the underlying oily surface could be slightly tacky at the moment of the design transfer [19, 26, 61-63]. Moreover, there are examples of pounced dots which rest upon an oil-based intermediate layer that have not been smudged by subsequent paint application, notably some by Rafael (1483-1520) [52].

Cross sections from reconstructions show this effect (Fig. 6), however the surfaces were not tacky prior to application as the previous authors assumed. While it is possible to see charcoal particles trapped in the oil layers, in fact in these reconstructions the oil was completely dry to the touch when the charcoal was applied. This phenomenon appears very similar to what is observed in the São Francisco paintings (Figs. 4c, 6b).

As opposed to an animal glue that dries upon evaporation of the water, drying oils such as linseed or walnut oil, show a complex and not yet fully understood drying and ageing process that involves concurrent mechanisms of autoxidation and polymerization, among other chemical reactions [64-66]. Although dry to the touch within a few weeks, an oil film continues to undergo changes that affect its properties throughout its life [66-68]. The slow drying time of the oil, even when pre-polymerized, could therefore be responsible for fixing any friable drawing material such as charcoal, as well as other soft stones that would mark the surface, including black stone.

Similarly, in the case of oiled charcoal, the non-drying olive oil that impregnates the stick would act as the binder of the charcoal particles, enabling smudge-resistant marks on the surface, independent of the presence of any sealing or imprimatura layer.

The lack of precise information in the historical sources pointing to the sources of black stone limits the relevance of the reconstructions using modern materials. However, the difficulty presented by the variable hardness of the black stone used does have a parallel in Armenini's De'veri precetti della pittura (1586). Regarding the behaviour of black stone when drawing on paper, Armenini states that a "Rough paper of little glue is used to conform to the quality of the stone repulsed by a clean surface" [40: p. 164]. In addition, he further comments that the stone, which according to Baldinucci (1681) [43: p. 92] came in large pieces ("pezzi assai grandicelli"), had to be "neither soft nor hard nor at all spongy for it breaks up into pieces", further warning that its tip could be "easily shattered and detached" [40: p. 164]. What was evident from the reconstructions is that the erasability of the marks with black stone was variable depending on which of the stones was used.

Regarding the position of the underdrawing in the paint structure, there is evidence of the use of dry mediasometimes identified analytically as 'black chalk'-drawn on top of imprimatura layers in paintings from Flemish, Dutch and Italian painters of the late fifteenth and sixteenth centuries $[16,17,19,33,51,60,69,70]$. Similarly, other works from the workshop of Francisco João, like the ones under study, have so far revealed the use of a dry material over an imprimatura, when the latter is present, or over a ground impregnated with an organic material on the surface [1].

Therefore, where there are well documented examples in oil paintings of the position of the underdrawing appearing on top of an oil-rich isolation layer/or imprimatura layer, the evidence from these reconstructions suggests that charcoal — and not only black stone-should be considered as a possible underdrawing material.

Furthermore, the behaviour of charcoal, notably in regard to its permanence, appears to be dependent on its position within the paint structure and on the nature of the binder of the intermediate layers. As such, technical reasons may lie at the root of the artist's choice regarding the location of the underdrawing within the paint structure. In fact, reconstructions have shown that an oil coating or an oil-rich imprimatura layer promotes the fixing of any dry and friable underdrawing media. Fluid underdrawing, most commonly aqueous-based, on the other hand, would presumably have had a greater tendency to pool and be repelled by a water resistant surface such as an oil-based imprimatura layer, as noted by some researchers $[33,71]$.

\section{Conclusions}

Reconstructions using charcoal (untreatated and oiled) and black stone over different isolation and imprimatura layers-designed to explore the behaviour of friable media within the complex multi-layered system 
of a sixteenth century panel painting-opened a new perspective on this subject by questioning the assumed impermanent character of charcoal.

Evidence based on these reconstructions and on analysis of a group of panel paintings by the Portuguese Mannerist Francisco João and his workshop demonstrate that an oil coating or an oil-rich imprimatura layer, although completely dry to the touch, still promotes the fixing of any friable underderdrawing material that is drawn over it, including charcoal. Therefore, it is proposed that charcoal and oiled charcoal might have been used in the underderdrawing stage of painting more frequently than suspected until now. These materials were inexpensive and easily prepared in the painter's workshop. In comparison with the modern black stones used in the reconstructions, charcoal and oiled charcoal were significantly easier to use.

This investigation further highlighted the close technical relationship between the choice of underdrawing materials, the selection of the oil or oil-based imprimatura intermediate layers and the position of the underdrawing within the paint structure.

\section{Supplementary Information}

The online version contains supplementary material available at https://doi. org/10.1186/s40494-022-00649-x.

Additional file 1: Appendix S1. Materials and suppliers.

Additional file 2: Appendix S2. Performance and appearance of the reconstructed underdrawing.

\section{Acknowledgements}

The lead author wishes to acknowledge the guidance and teachings of the late Bob Ghys at the outset of investigation in 2010. Thanks are due to Dr. Leslie Carlyle for her support and English editing and for providing, along with Raquel Marques, the HART linseed oils. Thanks too, to Jean-Yves Cordier who kindly provided a large piece of black stone collected in Crozon, Bretagne. In addition, the authors are grateful to Father Eduardo Pereira da Silva, Father Manuel da Silva Ferreira and Father António Nabais for facilitating access to the altarpieces, and also to Yigit Helvaci and Liciane Plouvier for their collaboration during the field work in the Sousel altarpiece.

\section{Authors' contributions}

HPM conceived the study, performed the visible and infrared analysis of the original paintings, designed the methodology for the reconstructions, prepared the materials and made the reconstructions, photographed the reconstructions in the binocular microscope, mounted the cross-sections of paint samples and reconstruction samples and made their analysis under the optical microscope (OM-UV-Vis). SV and HPM performed and interpreted the results of SEM-EDX analysis. HPM wrote the manuscript with English editing by Leslie Carlyle. AJC, SV and AC reviewed the manuscript. All authors read and approved the final manuscript.

\section{Funding}

This work was supported by the Fundação para a Ciência e Tecnologia (FCT), Portugal (Grant SFRH/BPD/109296/2015), Fundo Social Europeu (FSE), ERIHS. pt [ALT20-03-0145-FEDER-022115 (Program Alentejo2020)] and HERCULES Strategic Plan (UIDB/04449/2020 e UIDP/04449/2020).

\section{Availability of data and materials}

The datasets used and/or analysed during the current study as well as the reconstruction panels are available from the corresponding author on reasonable request.

\section{Declarations}

\section{Competing interests}

The authors declare that they have no competing interests.

\section{Author details}

${ }^{1}$ HERCULES Laboratory, University of Évora, Palácio do Vimioso, Largo Marquês de Marialva 8, 7000-809 Évora, Portugal. ${ }^{2}$ City University of Macau Chair in Sustainable Heritage, University of Évora, Casa Cordovil, 7000-651 Évora, Portugal. ${ }^{3}$ Instituto Politécnico de Tomar, Estrada da Serra, 2300-313 Tomar, Portugal.

Received: 12 November 2021 Accepted: 14 January 2022

Published online: 11 February 2022

\section{References}

1. Melo HPM. O Pintor Francisco João (Act. 1563-1595). Materiais e Técnicas na Pintura de Cavalete em Évora na Segunda Metade do Século XVI. PhD Dissertation. Porto:Universidade Católica Portuguesa. http://hdl.handle. net/10400.14/14977. 2012.

2. Winter J, Fitzhugh E. Pigments based on carbon. In: Berrie B, editor. Artists pigments A history of their history and characteristics, vol. 4. WashingtonLondon: National Gallery of Art-Archetype Publications; 2007. p. 1-37.

3. Bomford D, editor. Art in the Making: underdrawings in renaissance paintings. London: National Gallery London; 2002

4. Bescoby J, Rayner J, Tanimoto S. Dry drawing media. In: Higgitt C, Saunders D, Ambers J, editors. Italian renaissance drawings. Technical examination and analysis. London: Archetype Publications-The British Museum; 2010. p. 39-56.

5. Mayhew TD, Ellis M, Seraphin S. Natural black chalk in traditional old master drawings. JAIC. 2010;49(2):83-95. https://doi.org/10.1179/01971 3610804489955.

6. Winter J. The characterization of pigments based on carbon. Stud Con. 1983;28(2):49-66. https://doi.org/10.2307/1506050.

7. Spring M, Grout R, White R. 'Black Earths': a study of unusual black and dark grey pigments used by artists in the sixteenth century. Nat Gall Tech Bull. 2003;24:96-114.

8. Perego F. Dictionnaire des matériaux du peintre. Paris: Bélin; 2005.

9. Yvel C. Peindre à l'eau comme les maîtres. Dessin, lavis \& détrempe, techniques anciennes. Édisud: Aix-en-Provence; 2006.

10. Escribano R, Sloan JJ, Siddique N, Sze N, Dudev T. Raman spectroscopy of carbon-containing particles. Vibr Spect. 2001;26:179-86.

11. Pagès-Camagna S, Duval A, Guicharnaud H. Study of Gustave Moreau's black drawings: identification of the graphic materials by Raman microspectrometry and PIXE. J Raman Spectr. 2004;35:628-32. https://doi.org/ 10.1016/S0924-2031(01)00106-0.

12. Tomasini E, Siracisano G, Maier MS. Spectroscopic and chemical characterization of historical pigments based on carbon. Paths for the identification of an artistic pigment. Microchem J. 2012;102:28-37. https://doi.org/ 10.1016/j.microc.2011.11.005.

13. Coccato A, Jehlicka J, Moens L, Vandenabeele P. Raman spectroscopy for the investigation of carbon-based black pigments. J Raman Spectr. 2015:46:1003-15. https://doi.org/10.1002/jrs.4715.

14. Daly NS, Sullivan M, Lee L, Trentelman K. Multivariate analysis of Raman spectra of carbonaceous black drawing media for the in situ identification of historic artist materials. J Raman Spectr. 2018;49:1497-506. https:// doi.org/10.1002/jrs.5417.

15. Dunkerton J, Burnstock A, Smith A. Two wings of an Altarpiece by Martin van Heemskerck. Nat Gall Tech Bull. 1988;12:16-35.

16. Boersma A, van Loon A, Boon J. Rubens' oil sketches for the Achilles Series: a focus on the imprimatura layer and drawing material. Art Matt. 2007:4:482-9. 
17. Faries M. Jan van Scorel's drawing and painting technique. In: Faries M, Helmus LM, editors. Utrecht painting, 1363-1600, The Collection of the Centraal Museum Utrecht. Utrecht: Centraal Museum; 2011. p. 22-42.

18. Ainsworth MW.'Paternes for phisioneamyes': Holbein's portraiture reconsidered. Burl Mag. 1990;132(1044):173-86.

19. Currie C, Ghys B. Design transfer in Pieter Brueghel the Younger's workshop: a step-by-step reconstruction based on Technical examination of his Paintings. In: Verougstraete H, Couvert J, editors. La Peinture Ancienne et ses Procédés. Copies, Répliques, Pastiches: actes du Colloque XV pour l'étude du dessin sous-jacent dans la peinture. Paris-Leuven-Walpole: Uitgeverij Peeters Publishers; 2006. p. 196-206.

20. Sandner I. Underdrawings: transfer methods and identification using IRR. In: Verougstraete H, De Bisthoven JC, editors. The quest for the original: Proceedings of the Symposium XVI for the Study of the Underdrawing and Technology in Painting, Bruges, Sept. 2006. Bruges: Uitgeverij Peeters Publishers; 2009. p. 250-7.

21. Buijsen E. A rediscovered wing of a diptych by Hans Memling (c. 1440-1494). Oud Holl. 1996;110(2):57-69.

22. Leeflang M. Joos van Cleve's "Adoration of the Magi" in Detroit: revealing the underdrawing. Bull Detroit Inst Arts. 2008;82(1/2):60-75

23. Lammertse F, Wallert A, Wolters $M$. In search of the right colour: colour notations in a late sixteenth-century Dutch painting. In: Spring M, editor. Studying old master paintings technology and practice: Proceedings of The National Gallery Technical Bulletin 30th Anniversary Conference. London: Archetype Publications; 2011. p. 111-7.

24. Van Duijn E, Kok JPF, Vandivere A, Wallert A, Wolters M. Developments in the underdrawing and painting technique of the sixteenth-century Leiden School, in particular the workshops of Cornelis Engebrachtsz and Lucas van Leyden. In: Spring M, editor. Studying Old Master Paintings Technology and Practice: Proceedings of the National Gallery Technical Bulletin 30th Anniversary Conference. London: Archetype Publications; 2011. p. 104-10

25. Born A, Martens MPJ. Goossen van der Weyden and the transmission of the Rogeresque tradition from Brussels to Antwerp. In: Campbell L, Van der Stock J, Reynolds C, Watteew L, editors. Rogier van der Weyden in context papers presented at the Seventeenth Symposium for the Study of Underdawing and Technology in Painting held in Leuven, 22-24 October 2009. Paris-Leuven-Walpole: Peeters Publishers; 2012. p. 340-51.

26. Currie C, Saverwyns S, Depuyt-Elbaum L, Fraiture P, Glatigny JA, Coudray A. Lifting the veil: The Dulle Griet rediscovered through conservation, scientific imagery and analysis. In: Currie C, editor. The Brueghel Success Story. Peprints presented at the Symposium XXI for the Study of Underdrawing and Technology in Painting, Brussels, 12-14 September 2018. Leuven-Paris-Bristol: Peeters; 2021. p. 19-42.

27. Déroche C. Cennino Cennini II libro dell'arte [End 14th c.]. Paris: BergerLevrault; 1991.

28. Vasari G. Le Vite de' Più Eccellenti Architetti, Pittori et Scultori Italiani, (...). Firenze: Gallica; 1550.

29. Maclehose LS. Vasari on technique. New York: Dover Publications; 1960

30. Burns T. The invention of pastel painting. London: Archetype Publications; 2007

31. Stols-Witlox M. Historical recipes for preparatory layers for oils paintings in manuals, manuscripts and handbooks in North West Europe, 1550-1900: analysis and reconstructions. PhD Dissertation, vol. 2. Amsterdam: University of Amsterdam; 2014.

32. Verougstraete $H$. L'Imprimatura et la manière striée. Quelques exemples dans la peinture flamande du 15e au 17e siècle. In: Van Schoute R, Verougstraete-Marcq $\mathrm{H}$, editors. Infrarouge et autres techniques d'examen: actes du Colloque VI sur le dessin sous-jacent dans la peinture, 12-14 Sepetembre 1985. Louvain-la-Neuve: Collège Erasme; 1987. p. 21-7.

33. Vandivere A. Reconstructing intermediate layers in early Netherlandish Paintings. In: Wrapson L, Rose J, Miller R, Bucklow S, editors. In artists' footsteps. The reconstruction of pigments and paintings. Studies in honour of Renate Woudhuysen-Keller. London: Archetype Publications; 2012. p. 63-76.

34. Fels DC Jr. Lost secrets of Flemish Painting. Including the first complete English translation of the De Mayerne Manuscript, B. M. Sloane 2052. Hillsville: Alchemist Inc.; 2001.

35. Nismes HG. L'Art de Laver, ou la Nouvelle Maniere de Peindre sur le Papier Suivant le Coloris des Desseins qu'on envoie à la Cour [1687]. Gallica: Bruxelles; 1708.
36. Merrifield MP. Medieval and renaissance treatises on the arts of painting: original texts with English translations [1849]. New York: Dover Publications; 1999.

37. Van Mander K. Het Schilder-Boeck, Haarlem 1604. Utrecht: Davaco Publications; 1969

38. Noldus W. Karel Van Mander Principe et fondement de l'art noble et libre de la peinture [1604]. Paris: Belles Lettres; 2008.

39. Bruquetas-Galán R. Reglas para pintar. Un manuscrito anónimo de finales del siglo XVI. Ph Bol. 1988:24:33-44.

40. Olszewski EJ. Armenini's treatise on painting. PhD Dissertation. USA: University of Minnesota; 1974.

41. Du Grez BD. Traité sur la Peinture pour en apprendre la Teorie, \& se perfectionner dans la Pratique. Gallica: Toulouse; 1699

42. Larochelle $\mathrm{S}$. Historiographie des matériaux et des instruments du dessin à la Renaissance. Master Dissertation. Québec: Faculté des Lettres, Université Laval; 2005.

43. Baldinucci F. Vocabolario Toscano dell'Arte del Disegno (...). Gallica: Firenze; 1681.

44. Saywell E. Behind the line: the materials and techniques of Old Master Drawings. Harv Univ Art Mus Bull. 1998;6(2):7-39.

45. Ventura L. Arte da Pintura, Symmetria e Perspectiva Composta por Philippe Nunes [1615]. Porto: Editorial Paisagem; 1982.

46. Monteiro P, Cruz AJ. Breve Tratado de lluminação composto por um religioso da Ordem de Cristo. In: Afonso L, editor. The Materials of the Image. As Matérias da Imagem. Lisboa: Cátedra de Estudos Sefarditas Alberto Benveniste da Universidade de Lisboa; 2010. p. 237-86.

47. Hugas BB. Francisco Pacheco, Arte de la Pintura [1649]. Madrid: Cátedra; 2009.

48. Melo HP, Cruz AJ, Candeias A, Mirão J, Cardoso AM, Oliveira MJ, Valadas S. Problems of analysis by FTIR of calcium sulphate-based preparatory layers: the case of a group of 16th-century Portuguese paintings. Archaeometry. 2014;56(3):513-26. https://doi.org/10.1111/arcm.12026.

49. Kremer Pigmente. Linseed oil \#73020. https://www.kremer-pigmente. com/elements/resources/products/files/73020e.pdf. Accessed 30 Dec 2021. 2021.

50. Carlyle L. Historically accurate reconstructions of oil painter's materials: an overview of the HART project 2002-2005. In: Boon JJ, Ferreira ESB, editors. Reporting highlights of the De Mayerne Programme, MOLART report 13. The Hague: NWO; 2006. p. 63-77.

51. Foister S, Ashok R, Wyld M. Holbein's ambassadors. London: National Gallery Company; 1997.

52. Roy A, Spring M, Plazzotta C. Raphael's early work in the national gallery: paintings before Rome. Nat Gall Tech Bull. 2004;25:4-35.

53. Woollett AT, Szafran Y, Phenix A. Drama and devotion. Heemskerck's Ecce Homo Altarpiece from Warsaw. Los Angeles: J. Paul Getty Museum; 2012.

54. Ferreira ESB, Morrison R, Keune K, Boon JJ. Chemical characterization of thin intermediate layers: case study of a sample from the 15th century painting, The Descent from the Cross by Rogier van der Weyden. In: Boon JJ, Ferreira ESB, editors. Reporting highlights of the De Mayerne Programme. The Hague: NWO; 2006.

55. Félibien A. Des principes de l'Architecture, de la Sculpture, de la Peinture, et des autres arts qui en dépendent (...). Paris: Gallica; 1676.

56. Massing A. French painting technique in the seventeenth and early eighteenth centuries and De La Fontaine's Académie de la Peinture (Paris 1679). In: Hermens E, editor. Looking through paintings. The study of painting techniques and materials in support of art historical research, Leids Kunsthistorisch Jaarboeck. London: Archetype Publications; 1998. p. 319-90.

57. Veliz Z. Artists techniques in Golden Age Spain, Six treatises in translation. Cambridge: Cambridge University Press; 1986.

58. Corneille T. Dictionnaire Universel des Termes des Arts et des Sciences, vol. 2. Paris: Gallica; 1694.

59. Kapellakis IE, Konstantinos PT, Crowther J. Olive oil history, production and by-product management. Rev Environ Sci and Biotechnol. 2008;7:1-26. https://doi.org/10.1007/s11157-007-9120-9.

60. de Boer VAJRJ. Examen scientifique des peintures du groupe Jan van Scorel. In: Guillouet J, editor. Jan van Scorel d'Utrecht. Autels et tableaux de son atelier vers 1540. Documents. Examen scientifique. Douai: Musée de la Chartreuse; 1977. p. 51-5.

61. Ainsworth MW. Gérard David purity of vision in an age of transition. New York: The Metropolitan Museum of Art; 1998. 
62. Currie C, Ghys B. The Brueg(H)el phenomenon. Appendix III-practical reconstructions, vol. 3. Turnhout: Brepols Publishers; 2012. p. 956-79.

63. Caspers C, Verhave J, Wolters M. Reconstructing towards a better understanding: a study of missing underdrawings in Van Mierevelt's Portraits. In: Wrapson L, Rose J, Miller R, Bucklow S, editors. In artists'footsteps. The reconstruction of pigments and paintings. Studies in honour of Renate Woudhuysen-Keller. London: Archetype Publications; 2012. p. 95-108.

64. van der Weerd J, van Loon A, Boon JJ. FTIR studies of the effects of pigments on the aging of oil. Stud Cons. 2005;50(1):3-22. https://doi.org/10. 1179/sic.2005.50.1.3.

65. ledema PD, Hermans JJ, Keune K, van Loon A, Stols-Witlox MJN. Mathematical modeling of mature oil paint networks. In: Bridgland J, editor. ICOM-CC 17th Triennial Conference Preprints, Melbourne, 15-19 September 2014, art. 1604. Paris: International Council of Museums; 2014. p. 8.

66. Bonaduce I, Carlyle L, Colombini MP, Duce C, Ferrari C, Ribechini E, Selleri P, Tiné MR. New insights into the ageing of linseed oil paint binder: a qualitative and quantitative analytical study. PloS ONE. 2012;7(11):e49333. https://doi.org/10.1371/journal.pone.0049333.

67. Van der Berg JDJ, Boon J, Phenix A. Analytical chemistry of oil paint: a revised chemical model of aged oil paint relevant to the cleaning of paintings. In: Preprints of Beobachtungen zur Gemäldeoberflache und Möglichkeiten ihrer Behandlung, Schweizerischer Verband für Konservierung und Restaurierung. Berne: Schule für Gestaltung; 1998.

68. Erhardt D, Tumosa CS, Mecklenburg M. Long-term chemical and physical processes in oil paint films. Stud Cons. 2005;50:143-50. https://doi.org/10. 1179/sic.2005.50.2.143.

69. Wolters M, Wallert A. The Well-Stocked Kitchen. In: Wallert A, editor. Still lifes: techniques and style: an examination of paintings from the Rijksmuseum. Amsterdam—Zwolle: Rijksmuseum—Waanders; 1999. p. 40-3.

70. Derks KAJM. Blue cabbages and invisible onions. Discolouration in the oeuvre of Joachim Beuckelaer. Master Dissertation. Amsterdam: University of Amsterdam; 2017.

71. Faries $M$, Heller B, Levine D. The recently discovered underdrawings of the master of the Saint Ursula Legend's "Triptych of the Nativity." Bull Detroit Inst Arts. 1987;62(4):4-19.

\section{Publisher's Note}

Springer Nature remains neutral with regard to jurisdictional claims in published maps and institutional affiliations.

\section{Submit your manuscript to a SpringerOpen ${ }^{\circ}$ journal and benefit from:}

- Convenient online submission

- Rigorous peer review

- Open access: articles freely available online

- High visibility within the field

- Retaining the copyright to your article

Submit your next manuscript at $\boldsymbol{\text { springeropen.com }}$ 